\title{
Phylotypic Characterization of Mycobionts and Photobionts of Rock Tripe Lichen in East Antarctica
}

\author{
Merry Sailonga Faluaburu ${ }^{1}$, Ryosuke Nakai ${ }^{2}\left(\mathbb{D}\right.$, Satoshi Imura ${ }^{3,4}$ and Takeshi Naganuma ${ }^{1,5, *(\mathbb{D})}$ \\ 1 Graduate School of Biosphere Science, Hiroshima University, 1-4-4, Kagamiyama, Higashi-hiroshima, \\ Hiroshima 739-8528, Japan \\ 2 Applied Molecular Microbiology Research Group, Bioproduction Research Institute, \\ National Institute of Advanced Industrial Science and Technology, 2-17-2-1, Tsukisamu-higashi, \\ Toyohira Ward, Sapporo 062-8517, Japan \\ 3 National Institute of Polar Research, Research Organization of Information and Systems, 10-3, Midori-cho, \\ Tachikawa, Tokyo 190-8518, Japan \\ 4 SOKENDAI (The Graduate University for Advanced Studies), 10-3, Midori-cho, Tachikawa, Tokyo \\ 190-8518, Japan \\ 5 Graduate School of Integrated Sciences for Life, Hiroshima University, 1-4-4, Kagamiyama, \\ Higashi-hiroshima, Hiroshima 739-8528, Japan \\ * Correspondence: takn@hiroshima-u.ac.jp
}

Received: 13 June 2019; Accepted: 16 July 2019; Published: 18 July 2019

check for updates

\begin{abstract}
Saxicolous rock ripe lichens that grow on rocks in the East Antarctic fellfields were sampled for phylotypic characterization of its constituent mycobionts (fungi) and photobionts (algae and cyanobacteria). The rock tripe lichen-forming fungal and algal phylotypes were classified under the common lichen-forming genera of ascomycetes, namely, Umbilicaria, and green algae, namely, Trebouxia and Coccomyxa. However, phylotypes of the green algal chloroplasts and the lichen-associated cyanobacteria showed unexpectedly high diversity. The detected chloroplast phylotypes were not fully affiliated with the green algal genera Trebouxia or Coccomyxa. The predominant chloroplast phylotype demonstrated maximum resemblance to Neglectella solitaria, which is neither a known Antarctic species nor a typical lichen photobiont. Another dominant chloroplast phylotype belonged to the atypical Antarctic green algae family. Cyanobacterial phylotypes were dominated by those affiliated with the Microcoleus species rather than the well-known lichen-associates, Nostoc species. The occurrences of these Microcoleus-affiliated cyanobacterial phylotypes were specifically abundant within the Yukidori Valley site, one of the Antarctic Specially Protected Areas (ASPA). The ASPA site, along with another $50 \mathrm{~km}$-distant site, yielded most of the cryptic diversity in the phylotypes of chloroplasts and cyanobacteria, which may contribute to the phenotypic variability within the rock tripe lichen photobionts.
\end{abstract}

Keywords: lichens; symbiosis; mycobionts; photobionts; chloroplasts; cyanobacteria

\section{Introduction}

Lichens are composite organisms that arise from an association between filamentous fungi and photosynthetic organisms, commonly termed as mycobionts and photobionts, respectively, which has often been regarded as a good example of mutualistic symbiosis. Thus far, nearly 17,000-20,000 species of fungi, which account for approximately $20 \%$ of the extant species of fungi, are capable of lichenization [1]. It is well known that approximately $90 \%$ of lichens have less diverse green algal photobionts compared to the filamentous fungal partner, of which the two major genera include Trebouxia and Trentepohlia, along with the major cyanobacterial genus Nostoc [2]. Approximately 85\% of lichens have green algal photobionts, or chlorobionts; $10 \%$ have cyanobacterial photobionts, or cyanobionts; $3 \%$ have 
both photobionts, i.e., chloro- and cyano-bionts, to form tripartite (three membered) lichens; and the remaining $2 \%$ have brown or golden algae [3]. Lichens may have endolichenic or lichenicolous fungi, i.e., fungi present inside or on the surface of lichens, respectively. These fungi act as hidden potential producers of bioactive substances, such as detoxicants against anti-fungal substances from the lichen-forming fungi, antioxidants and lipase-/amylase-inhibitors, or necrotrophic/biotrophic parasites [4-6].

The presence of yeasts on lichens may act as possible third and fourth symbionts [7,8], suggesting that quadripartite or pentapartite (three fungi and one or two photobionts) is a common form of lichens. Therefore, lichens may be viewed as a multipartite micro-ecosystem, which harbors intricate biological and biogeochemical processes [9-11]. Lichens are also recognized as specific combat zones, composed of algal slaves and fungal exploiters, which are also characterized as niche seekers or take-over specialists, thus resulting in profound changes in the lichen microbiomes $[12,13]$.

As lichens have been broadly termed as mutualistic, they are successful colonizers in dominating the vegetation of over $6 \%$ of the land surface of the Earth [14]. The wide distribution and dominance of lichens is owed to its high adaptability and acclimatization to the different environmental conditions as a result of the phenotypic plasticity in thalli structure, respiration, photosynthesis, and tolerance to dryness [15-18]. Additionally, selection and switching of photobionts contribute to an increased adaptability [5,19-22] that would eventually allow the lichens to survive and thrive in the harshest of environments such as Antarctica. In Antarctica, approximately 400 species of lichens [23] have been studied for their diversity, ecophysiology, and photobiont diversity, which may eventually respond to environmental gradients and climate changes [24,25]. It is interesting to note that in an Antarctic-wide survey, 141 phylotypes of lichens were shown to be affiliated with the green algal genus Trebouxia [26].

Lichens, as a micro-ecosystem in general, would be more versatile and adaptable with the involvement of bacteria in its symbiotic association. Bacteria would aid in nitrogen acquisition by $\mathrm{N}_{2}$-fixation, phosphate mobilization, hydrolytic activities, and production of a hormone (indole-3-acetic acid), and lichens in turn would profit from the bacteria by increasing their life expectancy [27-30]. In this study, we conducted phylotypic characterization of the mycobionts and photobionts (algae and cyanobacteria) of rock tripe lichens in Antarctica. Interestingly, during characterization, we encountered unexpected phylotypic diversity of algal chloroplasts and cyanobacteria found in these rock tripe lichens. It is discussed that there might be a possible cryptic diversity of chloroplasts and cyanobacteria against less diverse fungal and algal phylotypes in the rock tripe lichens found in Antarctica.

\section{Materials and Methods}

\subsection{Collection of Rock Tripe Lichen Samples from Antarctica}

Samples of rock tripe lichens were collected between January and February 2011, during the 52nd Japanese Antarctic Research Expedition, at six different sites in the ice-free rocky fellfields, along the east coast (Sôya Coast) of Lützow-Holm Bay, near Syowa Station, in Queen Maud Land, East Antarctica (Figure 1; Table 1). The first site (area 1), Langhovde Hills (about $20 \mathrm{~km}$ south of the Japanese Syowa Station), was located in the northernmost part of the full studied field, and the sites were therein named as 1-1 and 1-2. The site named 1-1 was within the Antarctic Specially Protected Area (ASPA) 141, Yukidori Valley, and it is the same place from where sample 1-1 was collected. The southernmost part of the studied field was area 3, Skallen Hills, about $50 \mathrm{~km}$ from area 1, wherein sites 3-1 and 3-2 were marked. The remaining two sites, 2-1 and 2-2, were set in Skarvsnes Foreland, located in the center of Langhovde and Skallen Hills. It is important to note that these hills and foreland are divided by glaciers. 


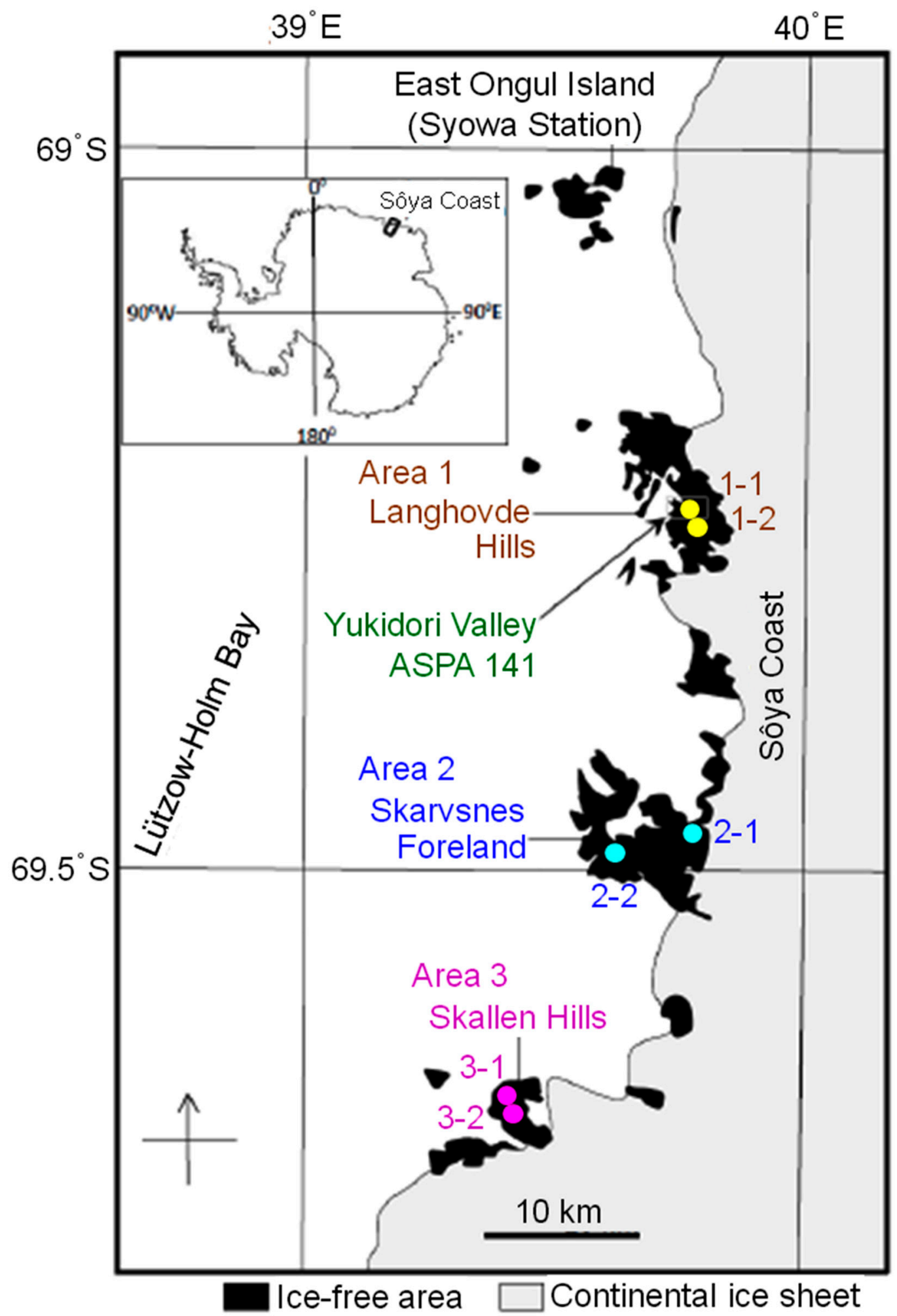

Figure 1. Location of sampling sites along the east coast (Sôya Coast) of Lützow-Holm Bay, near Syowa Station in Queen Maud Land, East Antarctica. Sites 1-1 and 1-2 are located in area 1, Langhovde Hills; sites 2-1 and 2-2 in area 2, Skarvsnes Foreland; and, sites 3-1 and 3-2 in area 3, Skallen Hills. 
Table 1. List of sampling sites of rock tripe lichen specimens along the east coast of Lützow-Holm Bay, Queen Maud Land, East Antarctica, and the numbers of sampled colonies.

\begin{tabular}{lcccc}
\hline \multicolumn{1}{c}{ Area } & Site/Sample & Longitude & Latitude & $\begin{array}{c}\text { No. of Sampled } \\
\text { Colonies }\end{array}$ \\
\hline 1. Langhovde Hills & $1-1$ & $69^{\circ} 14^{\prime} 38.9^{\prime \prime} \mathrm{S}$ & $39^{\circ} 44^{\prime} 59.3^{\prime \prime} \mathrm{E}$ & 1 \\
& $1-2$ & $69^{\circ} 15^{\prime} 38.0^{\prime \prime} \mathrm{S}$ & $39^{\circ} 47^{\prime} 03.7^{\prime \prime} \mathrm{E}$ & 1 \\
\hline \multirow{2}{*}{ 2. Skarvsnes Foreland } & $2-1$ & $69^{\circ} 27^{\prime} 37.2^{\prime \prime} \mathrm{S}$ & $39^{\circ} 47^{\prime} 15.6^{\prime \prime} \mathrm{E}$ & 1 \\
& $2-2$ & $69^{\circ} 29^{\prime} 27.0^{\prime \prime} \mathrm{S}$ & $39^{\circ} 36^{\prime} 09.6^{\prime \prime} \mathrm{E}$ & 1 \\
\hline \multirow{2}{*}{ 3. Skallen Hills } & $3-1$ & $69^{\circ} 40^{\prime} 22.0^{\prime \prime} \mathrm{S}$ & $39^{\circ} 24^{\prime} 11.1^{\prime \prime} \mathrm{E}$ & 2 \\
\hline
\end{tabular}

Six sites in three discrete areas were set. One sample per one site was used in this study and, thus, sample designations are the same as the designations of the corresponding sites.

Lichen thalli of size greater than $3 \mathrm{~cm}$ and growing in a $\sim 1$ m-wide colony were collected by cutting at the umbilicus attachments with flame-sterilized scalpel blades and tweezers, and were subsequently placed together in a pre-sterilized Whirl-Pak bag (Nasco, Fort Atkinson, WI, USA). One or two colonies were sampled at each site (Table 1). It is important to keep in mind that in this study, as only one sample per site was used for mycobiont and photobiont characterization, it may not necessarily represent the site. Lichen samples were kept in the dark in the field during collection, were kept frozen during transportation, and were stored at $-20^{\circ} \mathrm{C}$ in the laboratory freezer until use.

\subsection{DNA Extraction from the Lichen Thalli}

Approximately $1 \mathrm{~g}$ of dried thalli from a Whirl-Pak bag was weighed and then washed by dipping in autoclaved, $0.2 \mu \mathrm{m}$-filter-sterilized, deionized water, followed by grinding into pieces using sterilized mortars and pestles. Total lichen-derived DNA was extracted from the lichen pieces according to the instructions stated in the bead-beating method [31] using ISOIL for the beads beating kit (Nippon Gene, Tokyo, Japan). Precipitation of DNA was done with 100\% ethanol, which was facilitated by the addition of Ethachinmate (Nippon Gene, Tokyo, Japan). DNA precipitates were re-suspended in Tris-EDTA buffer ( $\mathrm{pH}$ 8.0) and assessed for quality and quantity using the NanoDrop 2000c (Thermo Fisher Scientific, Waltham, Massachusetts, USA). The resulting retrieved DNA from the lichen samples had a concentration ranging from $0.7 \mu \mathrm{g}$ to $10.5 \mu \mathrm{g}$ per sample, with purity (ratio of absorbance at $260 \mathrm{~nm}-280 \mathrm{~nm}$ ) ranging between 1.5 to 1.9 . The lichen-derived DNA samples were stored at $-20{ }^{\circ} \mathrm{C}$.

\subsection{Amplification, Cloning, and Sequencing of rRNA Gene-Related Sequences}

Phylotypes in this study were generated based on the sequences from dual methods, i.e., the conventional Sanger-sequencing method and the massive parallel sequencing technique using an Illumina MiSeq platform. The latter, MiSeq-sequencing, which is described in detail in Section 2.4, was used for profiling a small segment (V3-V4 region) of the 16S rRNA gene sequence in order to add information to the Sanger-based method of sequencing which was used to describe the chloroplast and cyanobacterial phylotypes. In this section, we describe the procedures involved in the Sanger-sequencing of near-full-length 18S RNA genes and internal transcribed spacer (ITS) region of the rRNA genes of fungal mycobionts and algal photobionts and near-full-length 16S RNA genes of the algae-derived chloroplasts and cyanobacteria.

\subsubsection{PCR Amplification of rRNA Gene-Related Sequences}

The thalli-derived DNA samples (obtained in Section 2.2) were used for the PCR amplification of near full-length 16S rRNA gene sequences of the chloroplasts and prokaryotes, as well as the fungal and algal near full-length 18S rRNA genes and ITS regions (between small- and large-subunit ribosomal RNA genes), by using a TaKaRa Thermal Cycler Dice (TaKaRa Bio, Kusatsu, Japan). All PCR amplifications were conducted with an initial denaturation at $94{ }^{\circ} \mathrm{C}$ for $5 \mathrm{~min} ; 30$ cycles of 
$94{ }^{\circ} \mathrm{C} 30 \mathrm{~s}, 56{ }^{\circ} \mathrm{C} 40 \mathrm{~s}$, and $72{ }^{\circ} \mathrm{C}$ for $1 \mathrm{~min}$; and the final elongation at $72{ }^{\circ} \mathrm{C}$ for $5 \mathrm{~min}$ [32], with thraustochytrid-derived [33] and the below-mentioned Escherichia coli TOP10 competent cell-derived DNAs as the eukaryotic and prokaryotic positive controls, respectively, and the non-DNA-added reactions as the negative control.

The eukaryotic universal primers for $18 \mathrm{~S}$ rRNA gene sequence, EukF and EukR [34], were used for the amplification of the lichen-forming fungal and algal 18S rRNA genes (Table 2) and were sequenced with M13F, M13R, and EuK516F primers [35] to obtain the near-full-length 18S rRNA gene sequences.

Table 2. List of primers used for PCR amplification of target sequences.

\begin{tabular}{|c|c|c|c|c|c|c|}
\hline Target Sequence & $\begin{array}{c}\text { Primer } \\
\text { Designation }\end{array}$ & Forward/Reverse & - mer & $5^{\prime} \rightarrow 3^{\prime}$ & $\begin{array}{l}\text { Expected Product } \\
\text { Size }\end{array}$ & Ref \\
\hline \multirow{2}{*}{$18 \mathrm{~S}$ rRNA gene } & EukF & $\mathrm{F}$ & 21 & AACCTGGTTGATCCTGCCAGT & Fungi, $2.0 \mathrm{kbp}$ & \multirow{2}{*}{ [34] } \\
\hline & EukR & $\mathrm{R}$ & 21 & TGATCCTTCTGCAGGTTCACC & Algae, $1.8 \mathrm{kbp}$ & \\
\hline \multirow{2}{*}{$\begin{array}{c}\text { Eukaryotic internal } \\
\text { transcribed spacer (ITS) }\end{array}$} & ITS1F & F & 22 & CTTGGTCATTTAGAGGAAGTAA & \multirow{2}{*}{$800 \mathrm{bp}$} & [36] \\
\hline & ITS4R & $\mathrm{R}$ & 20 & TCCTCCGCTTATTGATATGC & & [37] \\
\hline \multirow{2}{*}{ 16S rRNA gene } & $27 \mathrm{~F}$ & F & 20 & AGAGTTTGATCCTGGCTCAG & \multirow{2}{*}{$1.5 \mathrm{kbp}$} & \multirow{2}{*}{ [34] } \\
\hline & $1492 \mathrm{R}$ & $\mathrm{R}$ & 19 & GGTTACCTTGTTACGACTT & & \\
\hline \multirow{2}{*}{ V3-V4 of $16 \mathrm{~S}$ rRNA gene } & $341 \mathrm{~F}$ & F & 17 & CCTACGGGNGGCWGCAG & \multirow{2}{*}{$460 \mathrm{bp}$} & {$[38]$} \\
\hline & $806 \mathrm{R}$ & $\mathrm{R}$ & 21 & GACTACHVGGGTATCTAATCC & & [39] \\
\hline
\end{tabular}

Primers for sequencing purpose [31] are mentioned in the text. " $\mathrm{W}$ " in the $341 \mathrm{~F}$ sequence indicates the degenerated nucleotides of A or T; " $\mathrm{H}$ " in the 806R sequence indicates the degenerated nucleotides of A or C or T; and "V" also in the 806R sequence indicates the degenerated nucleotides of $\mathrm{A}$ or $\mathrm{C}$ or $\mathrm{G}$.

The ITS regions were amplified using the primer pair ITS1F and ITS4A [36,37] (Table 2). The 16S rRNA gene sequence of algae-derived chloroplasts, which acts as a marker for algae, as well as prokaryotes (including cyanobacteria), was amplified using the universal primers 27F and 1492R [34] (Table 2).

\subsubsection{Cloning and Sequencing of rRNA Gene-Related Sequences}

The PCR amplicons of fungal and algal 18S rRNA genes were distinguished electrophoretically by their pre-determined sizes of approximately $2.0 \mathrm{kbp}$ and $1.8 \mathrm{kbp}$, respectively. The electrophoretic bands on the agarose gels were excised for DNA extraction and re-amplification by PCR, with an aim to perform size-specific cloning followed by sequencing. The PCR amplicons of $16 \mathrm{~S}$ rRNA genes belonged to the algae-derived chloroplasts, cyanobacterial and non-cyanobacterial prokaryotes were collectively used for cloning and sequencing, however the non-cyanobacterial prokaryotic genes were eliminated later from phylotypic analyses.

The PCR amplicons were inserted into the plasmids, followed by transformation into Escherichia coli TOP10 competent cells for constructing the clone libraries by using the TOPO TA Cloning kit (Thermo Fisher Scientific, Waltham, MA, USA). The cloned amplicons were sequenced by the Sanger sequencing method, using the BigDye Terminator v3.1 Cycle Sequencing kit (Thermo Fisher Scientific) on an ABI 3730XL automatic DNA Sequencer (Thermo Fisher Scientific).

\subsection{Massive Parallel Sequencing of V3-V4 Region of the 16S rRNA Genes From the Algae-Derived Chloroplasts, Cyanobacteria, and Other Bacteria}

The hypervariable V3-V4 region of the prokaryotic 16S rRNA gene, consisting of approximately $460 \mathrm{bp}$, was amplified by PCR to construct the libraries for massive parallel sequencing, or next-generation sequencing, by using the MiSeq sequencer (Illumina, San Diego, CA, USA). The preparation of the 16S rRNA gene library began with PCR amplification using the V3-V4 region-specific primer pair 341F and 806R [38,39] (Table 2), which were tail-tagged with Illumina overhang adaptors and indexing barcodes. The target region was amplified using the Kapa HiFi HotStart ReadyMix PCR kit (Kapa Biosystems, Wilmington, MA, USA) on a Takara PCR Thermal Cycler Dice Touch (TaKaRa Bio, Kusatsu, Japan) under the following conditions: $95^{\circ} \mathrm{C}$ for 3 min with the lid heated at $110^{\circ} \mathrm{C} ; 25$ cycles of $95^{\circ} \mathrm{C}$ for $30 \mathrm{~s}, 55^{\circ} \mathrm{C}$ for $30 \mathrm{~s}$, and $72{ }^{\circ} \mathrm{C}$ for $30 \mathrm{~s}$; and a final elongation at $72{ }^{\circ} \mathrm{C}$ for $5 \mathrm{~min}$, held at $4{ }^{\circ} \mathrm{C}$ thereafter. 
Successful PCR amplicons were purified with the magnetic bead-based Agencourt AMPure XP (Beckman Coulter, Indianapolis, IN, USA). Using the purified amplicons as templates, the second PCR cycle was performed in order to index the amplicons with the Nextera XT indexing primers of S501-S508 and N701-N712 (Illumina). The same PCR condition was employed, except that 8 cycles were used, instead of the previous 25 cycles. The second PCR amplicons were purified as stated above, equimolarly pooled, and run on an Agilent Bioanalyser 2100 (Agilent Technologies, Santa Clara, CA, USA) for quality analysis. The pooled samples were denatured, diluted, combined with the dual-indexed control bacteriophage PhiX, and sequenced on a MiSeq sequencer using the MiSeq Reagent Kit V3 (Illumina) to obtain paired-end $(2 \times 300 \mathrm{bp})$ reads.

\subsection{Data Analysis and Phylotype Determination}

We retrieved and analyzed the DNA sequences being classified as fungi, algae, algal-derived chloroplasts, or cyanobacteria. In this study, the non-cyanobacterial prokaryotic sequences, as well as the non-chloroplast organelle sequences, were eliminated.

The Sanger-generated sequences of the $18 \mathrm{~S}$ rRNA gene and ITS region were aligned by ClustalW multiple alignment program [40] using the BioEdit sequence alignment editor [41]. After excluding the low-quality sequences, the remaining sequences were manually assembled. Chimeric sequences were checked by tree topology analysis [42]. The resulting sequences were grouped into phylotypes, or operational taxonomic units (OTUs), at a sequence similarity cutoff value of $97 \%$ using the CD-HIT program $[43,44]$. A phylotype sequence was represented by the most abundant variant sequence. The phylotypes determined were searched against the NCBI nucleotide (nt) database using BLAST [45]. The sequences that hit with the fungal and algal sequences were used for further phylogenetic tree construction.

For the 16S rRNA gene data, the Sanger-generated sequences were processed following the same method as described above. After the BLAST search, the chloroplast and cyanobacterial sequences were used for the chimera-check analysis, as outlined below. The MiSeq-generated pair-end reads were assembled using fastq-join [46]. After trimming the barcode and primer sequences, the ambiguous sequences that were $<300 \mathrm{nt}$ and had a low average quality score $(<25)$ were removed. The taxonomic assignment of the quality-filtered sequences was processed in the web-based tool (https://www.ezbiocloud.net/contents/16smtp) provided by EzBioCloud [47]; a minor modification from the general data-processing procedure was done, not to eliminate the chloroplast $16 \mathrm{~S}$ sequence. This tool employs a software called CLcommunity (also referred to as BIOiPLUG; ChunLab, Seoul, Korea). This software has been previously used for analyzing microbial community structures [48,49]. Briefly, the method involves denoising the sequences to remove the errors generated by the sequencing process using DUDE-Seq [50]. After denoising, the sequences were compared against the EzBioCloud $16 \mathrm{~S}$ database, constructed from the curated 16S rRNA gene sequences using BLAST.

The cut-off value (97\%) for species-level identification was set according to the previous study [47]. The other cut-offs for genus or higher taxonomic ranks were set according to Yarza et al. [51]. Chimeras of the sequences that did not match at the species level $(\geq 97 \%)$ were checked using the UCHIME program [52] and the EzBioCloud's chimera-free reference database (https://help.ezbiocloud.net/ user-guide/mtp-pipeline/chimera-detection/), and the identified chimeric sequences were removed. In this process, the chimeras in the abovementioned Sanger-generated sequences were also assessed. After taxonomical assignment of the retrieved sequences to the chloroplasts and cyanobacteria, these sequences were clustered using CD-HIT at $97 \%$ sequence identity cutoff value in order to obtain the phylotype. Singleton sequences were removed during the phylotype picking process, as described in a previous study [53]. The representative phylotypes in the final data set were searched against the NCBI nucleotide database using BLAST.

The Sanger-generated sequences were deposited in the DDBJ/ENA/GenBank database under the accession numbers LC487916 to LC487925, LC487926 to LC487929, and LC487713 to LC487717, for the $18 \mathrm{~S}$ rRNA gene, ITS, and 16S rRNA gene phylotypes, respectively. The MiSeq-generated sequence data 
is available at DDBJ/ENA/GenBank under the BioProject number PRJDB8443. The BioSample numbers are SAMD00175323 to SAMD00175328. The DRA accession number is DRA008580.

\subsection{Diversity Indices and Phylogenetic Tree Analyses of the Phylotypes}

The Simpson diversity index was calculated based on the number of phylotypes that compose a genus as well as the number of sequences that compose a phylotype using the PAST 3.25 software [54].

Phylogenetic trees with the phylotypes and closely related sequences were constructed using MEGA 7 [55]. Multiple sequence alignments and evolutionary analyses were conducted using CLUSTAL W [40]. The evolutionary history of the sequences was inferred using the Maximum Composite Likelihood method [56] based on Kimura 2-parameter distances [57].

Dendrograms and heatmaps were generated based on cluster analyses of sample-specific occurrences of phylotypes by using the Heatmapper [58] with average linkage clustering and Euclidean distance measurement.

\section{Results and Discussion}

\subsection{Phylotype Diversity}

In this study, overall, a total of 116,937 sequences of rRNA operon components, i.e., near full-length $18 \mathrm{~S}$ and $16 \mathrm{~S}$ rRNA genes, eukaryotic ITS region between the large and small rRNA genes, and the V3-V4 region of $16 \mathrm{~S}$ rRNA genes, were obtained from the six lichen samples, which were collected at the six sites within a $50 \mathrm{~km}$-range in East Antarctica (Figure 1; Table 1). As noted above, this study focuses on the sequences affiliated with fungi, algae, algae-derived chloroplasts, and cyanobacteria; other organisms such as the non-cyanobacterial prokaryotic phylotypes were removed from the present report. Similar sequences were grouped into phylotypes, based on the categories of fungi, algae, algae-derived chloroplasts, and cyanobacteria, based on a $97 \%$ similarity cutoff value. Singleton sequences, not single phylotypes, in the MiSeq-sequenced V3-V4 region were excluded from the analysis. As a result, a total of 57 phylotypes were generated from an overall 116,937 sequences at a $97 \%$ similarity cutoff value, resulting in a phylotypic outlook of the lichen composites with taxa affiliations at the genus and higher levels (Table 3).

A $97 \%$ similarity cutoff, or threshold, has been commonly used to generate the prokaryotic phylotypes from 16S rRNA gene sequences [59] despite its intrinsic problems [60]. In a recent study, it was shown that the advanced MiSeq-sequencing of the V3-V4 region of 16S rRNA gene employing the $97 \%$ cutoff value was used to generate the phylotypes, which may result in over-merging, i.e., grouping two or more species into one. The use of higher cutoff values such as $98 \%$ and $99 \%$ would yield more specific phylotypes. However, an estimate of over-merging at $97 \%, 98 \%$, and $99 \%$ cutoffs are $5 \%-45 \%, 5 \%-41 \%$, and $5 \%-36 \%$, respectively, which may not necessarily be a significant improvement by raising the cutoffs [61]. Despite possible underestimation in the eukaryotic diversity caused by over-merging [62], the $97 \%$ cutoff has also been applied to eukaryotic ITS [63] and the 18S rRNA gene [64]. Therefore, the $97 \%$ cutoff is reasonably employed in this phylotypic study. 
Table 3. Numbers of phylotypes and phylotype-composing sequences affiliated with the most closely related taxa by BLAST.

\begin{tabular}{|c|c|c|c|c|c|c|c|}
\hline & & Class & Order & Family & Genus & Phylotype Number (\%) Codes & Sequence Number (\%) \\
\hline \multirow{2}{*}{ Fungi } & $18 \mathrm{~S}$ & Lecanoromycetes & Umbilicariales & Umbilicariaceae & Umbilicaria & $8(14.0 \%)$ F01-F08 & $21(0.018 \%)$ \\
\hline & ITS & Lecanoromycetes & Umbilicariales & Umbilicariaceae & Umbilicaria & $2(3.5 \%)$ F09, F10 & $6(0.005 \%)$ \\
\hline \multirow{3}{*}{ Algae } & \multirow{2}{*}{$18 \mathrm{~S}$} & \multirow{2}{*}{ Trebouxiophyceae } & \multirow{2}{*}{ Trebouxiales } & Coccomyxaceae & Coccomyxa & $1(1.8 \%) \mathrm{A} 01$ & $2(0.002 \%)$ \\
\hline & & & & Trebouxiaceae & Trebouxia & $1(1.8 \%) \mathrm{A} 02$ & $6(0.005 \%)$ \\
\hline & ITS & Trebouxiophyceae & Trebouxiales & Trebouxiaceae & Trebouxia & $2(3.5 \%) \mathrm{A} 03, \mathrm{~A} 04$ & $6(0.005 \%)$ \\
\hline \multirow{10}{*}{ Chloro-plasts } & \multirow{6}{*}{$16 S$} & \multirow{4}{*}{ Trebouxiophyceae } & \multirow[b]{2}{*}{ Trebouxiales } & Coccomyxaceae & Coccomyxa & $2(3.5 \%) \mathrm{T} 01, \mathrm{~T} 02$ & $4(0.003 \%)$ \\
\hline & & & & Trebouxiaceae & Myrmecia & $1(1.8 \%)$ T05 & $60(0.051 \%)$ \\
\hline & & & \multirow{2}{*}{$\begin{array}{l}\text { Microthamniales } \\
\text { Chlorellales }\end{array}$} & Microthamniaceae & Microthamnion & $1(1.8 \%) \mathrm{T} 04$ & $13(0.011 \%)$ \\
\hline & & & & Oocystaceae & Planctonema & $1(1.8 \%) \mathrm{T} 06$ & $3(0.003 \%)$ \\
\hline & & \multirow{2}{*}{ Chlorophyceae } & \multirow{2}{*}{ Chlamydomonadales } & incertae sedis & Ettlia & $1(1.8 \%) \mathrm{T} 03$ & $13(0.011 \%)$ \\
\hline & & & & Chlorellaceae & Chloroidium & $1(1.8 \%) \mathrm{T} 11$ & $3(0.003 \%)$ \\
\hline & \multirow{4}{*}{ V3-V4 } & \multirow{4}{*}{ Trebouxiophyceae } & \multirow[t]{2}{*}{ Chlorellales } & Oocystaceae & Neglectella & $1(1.8 \%) \mathrm{T} 12$ & $114,009(97.496 \%)$ \\
\hline & & & & incertae sedis & Picochlorum & $1(1.8 \%) \mathrm{T} 07$ & $2(0.002 \%)$ \\
\hline & & & \multirow{2}{*}{$\begin{array}{l}\text { Prasiolales } \\
\text { Trebouxiales }\end{array}$} & Prasiolaceae & Edaphochlorella & $3(5.3 \%)$ T08-T10 & $1216(1.040 \%)$ \\
\hline & & & & Coccomyxaceae & Coccomyxa & $2(3.5 \%) \mathrm{T} 13, \mathrm{~T} 14$ & $83(0.071 \%)$ \\
\hline \multirow{15}{*}{ Cyano-bacteria } & \multirow[t]{8}{*}{$16 \mathrm{~S}$} & \multirow[t]{7}{*}{ Cyanophyceae } & \multirow[t]{2}{*}{ Synechococcales } & Leptolyngbyaceae & Leptolyngbya & $1(1.8 \%) \mathrm{C} 01$ & $1(0.001 \%)$ \\
\hline & & & & Oscillatoriaceae & Phormidium & $3(5.3 \%) \mathrm{C} 02, \mathrm{C} 06, \mathrm{C} 12$ & $55(0.047 \%)$ \\
\hline & & & \multirow{5}{*}{ Oscillatoriales } & \multirow{2}{*}{ Microcoleaceae } & Microcoleus & $5(8.8 \%)$ C03-C05 C14, C15 & $953(0.815 \%)$ \\
\hline & & & & & Pseudophormidium & $1(1.8 \%) \mathrm{C} 07$ & $2(0.002 \%)$ \\
\hline & & & & Coleofasciculaceae & Wilmottia & $1(1.8 \%)$ C 16 & $34(0.029 \%)$ \\
\hline & & & & Gomontiellaceae & Crinalium & $1(1.8 \%) \mathrm{C} 17$ & $57(0.049 \%)$ \\
\hline & & & & Chamaesiphonaceae & Chamaesiphon & $1(1.8 \%)$ C08 & $5(0.004 \%)$ \\
\hline & & \multirow{8}{*}{ Cyanophyceae } & \multirow[t]{2}{*}{ Synechococcales } & \multirow{2}{*}{ Leptolyngbyaceae } & Leptolyngbya & $1(1.8 \%) \mathrm{C} 11$ & $2(0.002 \%)$ \\
\hline & \multirow{7}{*}{ V3-V4 } & & & & Stenomitos & $1(1.8 \%) \mathrm{C} 13$ & $2(0.002 \%)$ \\
\hline & & & \multirow{2}{*}{ Chroococcidiopsi-dales } & Chroococcidiopsi-daceae & Chroococcidiopsis & $1(1.8 \%)$ C 18 & $4(0.003 \%)$ \\
\hline & & & & Nostocacea & Nostoc & $2(3.5 \%) \mathrm{C} 27, \mathrm{C} 28$ & $17(0.015 \%)$ \\
\hline & & & \multirow{4}{*}{ Nostocales } & Godleyaceae & Toxopsis & $2(3.5 \%)$ C $24, C 26$ & $204(0.174 \%)$ \\
\hline & & & & Tolypothrichaceae & Tolypothrix & $1(1.8 \%) C 25$ & $12(0.010 \%)$ \\
\hline & & & & Stigonemataceae & Stigonema & $1(1.8 \%)$ C29 & $31(0.027 \%)$ \\
\hline & & & & Uncultured / unclassified & & $7(12.3 \%) \mathrm{C} 09, \mathrm{C} 10, \mathrm{C} 19-\mathrm{C} 23$ & $111(0.094 \%)$ \\
\hline
\end{tabular}

Phylotypes were grouped at a $97 \%$ similarity cutoff value for near full-length $18 \mathrm{~S}$ rRNA genes and eukaryotic ITS regions of lichen-forming fungi and algae, and near full-length and partial

V3-V4 region of 16S rRNA genes of algae-derived chloroplasts and cyanobacteria. Relative abundances (\% of total 57 phylotypes or 116,937 sequences) are shown in the parentheses. 
As the samples were collected from six sites within a relatively narrow range (Figure 1) and used in a one-sample-per-site manner, the phylotypes in the samples were collectively analyzed to calculate the diversity indices such as the Simpson index (1- $\lambda$ ) at a genus level (Figure 2). The calculation was based on the number of phylotypes that compose a genus (Figure 2, A) as well as the number of sequences that compose a phylotype (Figure 2, B). Categories that yielded only one genus, i.e., fungal 18S/ITS, algal ITS, and cyanobacterial 16S, resulted in the Simpson index value of 0 . Chloroplasts and cyanobacteria showed relatively high diversity based on the V3-V4 phylotypes. However, based on these sequences, the Simpson index values became lower due to the uneven distribution of the phylotype-composing sequences, as the Simpson index is a measure of species' richness and evenness. The chloroplast $16 \mathrm{~S}$ and cyanobacterial V3-V4 resulted in relatively higher diversity than each of the other categories.

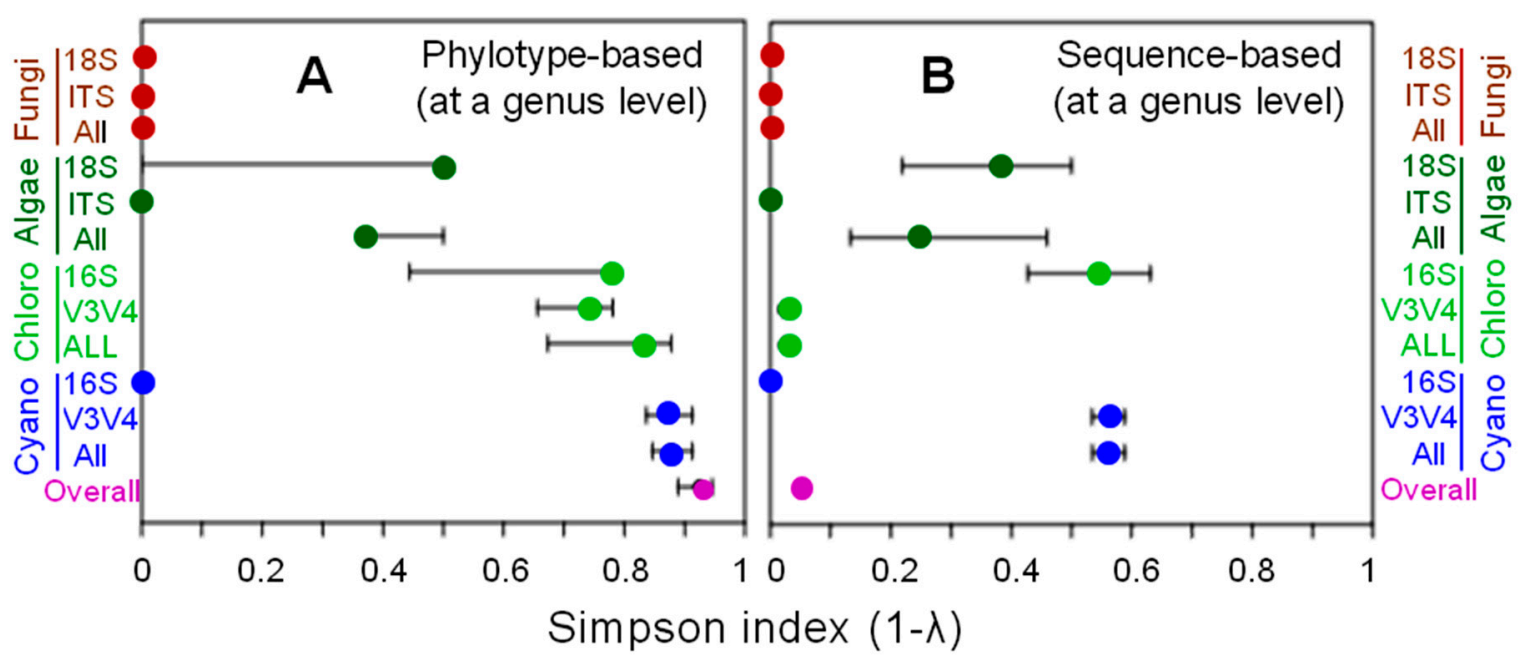

Figure 2. Simpson index (1- $\lambda)$ as a measure of diversity based on the number of phylotypes that compose a genus (A) as well as the number of sequences that compose a phylotype (B) of (from top to bottom) lichen-forming fungi, algae, algae-derived chloroplasts, cyanobacteria, and overall (Table 3). Simpson index values with error bars were calculated for: the phylotypes of fungal/algal 18S rRNA gene and ITS region; and of chloroplast/cyanobacterial 16S rRNA gene and V3-V4 region. The actual lower and upper values of the error bars as well as the actual index values are tabulated in Supplementary Table S1.

\subsection{Phylotype Composition}

From a total of 57 phylotypes, 10 were found to be fungal (consisting of 27 sequences), 4 were algal (14 sequences), 14 were chloroplast-derived (115,406 sequences), and 29 were cyanobacterial (1490 sequences), as summarized in Tables 3 and 4. Further, 10 fungal phylotypes were affiliated with the representative lichen-forming genus Umbilicaria, and 4 algal phylotypes were affiliated with the two representative lichen-hosted green algal genera of Trebouxia and Coccomyxa. In contrast, the 14 chloroplast phylotypes were affiliated with 10 green algal genera comprising Coccomyxa, Trebouxia, Myrmecia, Microthamnion, Planctonema, Ettlia, Chloroidium, Neglectella, Picochlorum, and Edaphochlorella, which may represent diverged lineages, or cryptic diversity, in the chloroplasts [60]. In addition, 29 cyanobacterial phylotypes were affiliated with 13 genera, including the most commonly known cyanobiont genus Nostoc [2], along with unclassified ones, which may suggest high variations in the cyanobacterial species that form associations with lichens, as well as opportunistic associations.

Compared to the Sanger-based sequences of near full-length 18S and 16S rRNA genes and the ITS region, the MiSeq-sequences of the V3-V4 region were abundant in numbers as the V3-V4 region, in general, is a part of the 16S rRNA gene and, therefore, some of the retrieved V3-V4 sequences are expected to show a $100 \%$ match with those of the $16 \mathrm{~S}$ rRNA gene sequences, which were amplified 
separately but were from the same DNA source. However, only few 100\% matches were detected, possibly because of the differences in amplification regions (targeted sequences and used primers), presence or absence of the cloning step, and sequencing methodologies. Although the exact reason for the rare occurrence of $100 \%$ matches is not clear yet, mismatches between Sanger- and MiSeq-sequencing has become a growing issue in studies involving fungal pathogens [65] and lichen photobionts [9]. According to Paul et al. [9], Sanger sequencing generally failed when the second most abundant photobiont exceeded $30 \%$ of the total MiSeq reads in a sample. The second most abundant V3-V4 phylotype in each sample, of either chloroplasts or cyanobacteria, did not exceed $30 \%$ of the total reads of the sample (Table 4) and, therefore, the conclusion highlighted by Paul et al. [9] did not apply to this study.

Table 4. Distribution of the numbers of phylotype-composing sequences (overall total 116,937) in lichen samples.

\begin{tabular}{|c|c|c|c|c|c|c|c|c|c|c|c|c|}
\hline & \multirow[t]{2}{*}{ Seq: } & \multirow[t]{2}{*}{ Code } & \multicolumn{3}{|c|}{ Closest sequence } & \multicolumn{2}{|c|}{$\begin{array}{c}\text { Area } 1 \\
\text { Langhovde }\end{array}$} & \multicolumn{2}{|c|}{$\begin{array}{c}\text { Area } 2 \\
\text { Skarvsnes }\end{array}$} & \multicolumn{2}{|c|}{$\begin{array}{c}\text { Area } 3 \\
\text { Skallen }\end{array}$} & \multirow[t]{2}{*}{ Sum } \\
\hline & & & Organism & Accession no. & Similarity (\%) & $1-1$ & $1-2$ & $2-1$ & $2-2$ & $3-1$ & $3-2$ & \\
\hline \multirow{11}{*}{ 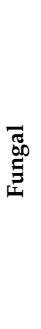 } & \multirow{7}{*}{$18 \mathrm{~S}$} & F01 & Umbilicaria rhizinata & KY948011 & 99.6 & 0 & 0 & 0 & 0 & 0 & 2 & 2 \\
\hline & & F02 & U. rhizinata & KY948011 & 99.7 & 0 & 0 & 0 & 0 & 0 & 2 & 2 \\
\hline & & F03 & U. rhizinata & KY948001 & 99.2 & 0 & 0 & 0 & 0 & 0 & 1 & 1 \\
\hline & & F04 & U. decussata & KY948001 & 99.2 & 3 & 0 & 0 & 0 & 0 & 0 & 3 \\
\hline & & F05 & U. decussata & KY948001 & 97.1 & 0 & 1 & 4 & 3 & 1 & 0 & 9 \\
\hline & & F06 & U. decussata & KY948001 & 93.9 & 0 & 1 & 0 & 0 & 0 & 0 & 1 \\
\hline & & F07 & U. decussata & KY948001 & 95.1 & 0 & 0 & 0 & 0 & 1 & 0 & 1 \\
\hline & \multirow{4}{*}{ ITS } & F08 & U. decussata & KY948001 & 91.0 & 0 & 1 & 0 & 0 & 1 & 0 & 2 \\
\hline & & F09 & U. aprina & FN185931 & 99.5 & 1 & 1 & 1 & 1 & 1 & 0 & 5 \\
\hline & & F10 & U. africana & KY947743 & 98.7 & 0 & 0 & 0 & 0 & 0 & 1 & 1 \\
\hline & & \multicolumn{2}{|r|}{ Fungal total } & \multicolumn{2}{|c|}{10 phylotypes } & 4 & 4 & 5 & 4 & 4 & 6 & 27 \\
\hline \multirow{5}{*}{ 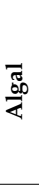 } & \multirow{2}{*}{$18 \mathrm{~S}$} & A01 & $\begin{array}{l}\text { Coccomyxa viridis } \\
\text { Trebouxiophyceae }\end{array}$ & HG973007 & 99.7 & 0 & 0 & 0 & 0 & 0 & 2 & 2 \\
\hline & & A02 & Trebouxia sp. SAG 2463 & KM020032 & 99.7 & 0 & 0 & 0 & 0 & 0 & 6 & 6 \\
\hline & \multirow{3}{*}{ ITS } & A03 & Trebouxia sp. URa2 & JN204815 & 100 & 1 & 1 & 1 & 1 & 0 & 0 & 4 \\
\hline & & A04 & Trebouxia sp. FP-2018 & MH299127 & 100 & 0 & 0 & 0 & 0 & 1 & 1 & 2 \\
\hline & & & Algal total & \multicolumn{2}{|c|}{4 phylotypes } & 1 & 1 & 1 & 1 & 1 & 9 & 14 \\
\hline \multirow{15}{*}{$\begin{array}{l}\frac{n}{d} \\
\frac{\pi}{2} \\
\frac{2}{2} \\
\frac{0}{2} \\
\frac{0}{d}\end{array}$} & \multirow{15}{*}{ V3-V4 } & $\mathrm{T} 01$ & $\begin{array}{l}\text { Coccomyxa glaronensis } \\
\text { Trebouxiophyceae }\end{array}$ & AM292034 & 92.8 & 0 & 0 & 0 & 0 & 0 & 3 & 3 \\
\hline & & $\mathrm{T} 02$ & $\begin{array}{l}\text { Coccomyxa sp. } \\
\text { Trebouxiophyceae }\end{array}$ & MF805805 & 90.1 & 0 & 0 & 0 & 0 & 0 & 1 & 1 \\
\hline & & T03 & $\begin{array}{l}\text { Ettlia pseudoalveolaris } \\
\text { Chlamydomonadales }\end{array}$ & KM462869 & 87.6 & 0 & 0 & 0 & 2 & 1 & 10 & 13 \\
\hline & & $\mathrm{T} 04$ & $\begin{array}{c}\text { Microthamnion } \\
\text { kuetzingianumTrebouxiophyceae }\end{array}$ & KM462876 & 84.6 & 0 & 1 & 1 & 1 & 0 & 10 & 13 \\
\hline & & T05 & $\begin{array}{l}\text { Myrmecia israelensis } \\
\text { Trebouxiophyceae }\end{array}$ & KM462861 & 88.3 & 0 & 1 & 0 & 35 & 14 & 10 & 60 \\
\hline & & T06 & $\begin{array}{l}\text { Planctonema lauterbornii } \\
\text { Trebouxiophyceae }\end{array}$ & KM462880 & 88.0 & 0 & 0 & 0 & 2 & 0 & 1 & 3 \\
\hline & & $\mathrm{T} 07$ & $\begin{array}{l}\text { Picochlorum eukaryotum } \\
\text { Trebouxiophyceae }\end{array}$ & X76084 & 81.9 & 0 & 0 & 0 & 2 & 0 & 0 & 2 \\
\hline & & T08 & $\begin{array}{l}\text { Edaphochlorella mirabilis } \\
\text { Trebouxiophyceae }\end{array}$ & X65100 & 94.8 & 0 & 0 & 0 & 0 & 3 & 1 & 4 \\
\hline & & T09 & $\begin{array}{l}\text { Edaphochlorella mirabilis } \\
\text { Trebouxiophyceae }\end{array}$ & X65100 & 92.1 & 212 & 89 & 116 & 158 & 348 & 260 & 1183 \\
\hline & & $\mathrm{T} 10$ & $\begin{array}{l}\text { Edaphochlorella mirabilis } \\
\text { Trebouxiophyceae }\end{array}$ & X65100 & 94.8 & 23 & 2 & 3 & 0 & 0 & 1 & 29 \\
\hline & & $\mathrm{T} 11$ & $\begin{array}{l}\text { Chloroidium saccharophilum } \\
\text { Trebouxiophyceae }\end{array}$ & D11349 & 97.7 & 0 & 0 & 0 & 0 & 0 & 3 & 3 \\
\hline & & $\mathrm{T} 12$ & $\begin{array}{l}\text { Neglectella solitaria } \\
\text { Trebouxiophyceae }\end{array}$ & FJ968739 & 92.8 & 21,375 & 5772 & 10,596 & 7924 & 14,065 & 54,277 & 114,009 \\
\hline & & $\mathrm{T} 13$ & $\begin{array}{l}\text { Coccomyxa subellipsoidea } \\
\text { Trebouxiophyceae }\end{array}$ & HQ693844 & 91.6 & 0 & 0 & 0 & 2 & 0 & 3 & 5 \\
\hline & & \multirow[t]{2}{*}{ T14 } & $\begin{array}{l}\text { Coccomyxa simplex } \\
\text { Trebouxiophyceae }\end{array}$ & AM292034 & 95.7 & 0 & 0 & 0 & 0 & 0 & 78 & 78 \\
\hline & & & Chloroplast total & \multicolumn{2}{|c|}{14 phylotypes } & 21,610 & 5865 & 10,716 & 8126 & 14,431 & 54,658 & 115,406 \\
\hline
\end{tabular}


Table 4. Cont.

\begin{tabular}{|c|c|c|c|c|c|c|c|c|c|c|c|c|}
\hline & \multirow[t]{2}{*}{ Seq: } & \multirow[t]{2}{*}{ Code } & \multicolumn{3}{|c|}{ Closest sequence } & \multicolumn{2}{|c|}{$\begin{array}{c}\text { Area } 1 \\
\text { Langhovde }\end{array}$} & \multicolumn{2}{|c|}{$\begin{array}{c}\text { Area } 2 \\
\text { Skarvsnes }\end{array}$} & \multicolumn{2}{|c|}{$\begin{array}{c}\text { Area } 3 \\
\text { Skallen }\end{array}$} & \multirow[t]{2}{*}{ Sum } \\
\hline & & & Organism & Accession no. & Similarity (\%) & 1-1 & $1-2$ & $2-1$ & $2-2$ & $3-1$ & $3-2$ & \\
\hline \multirow{30}{*}{ 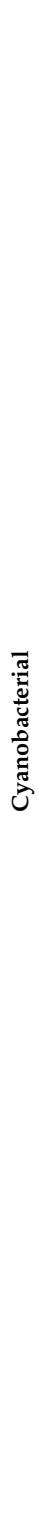 } & $16 \mathrm{~S}$ & $\mathrm{C} 01$ & $\begin{array}{l}\text { Leptolyngbya antarctica } \\
\text { Synechococcales }\end{array}$ & AY493590 & 98.2 & 0 & 0 & 0 & 0 & 0 & 1 & 1 \\
\hline & \multirow{29}{*}{ V3-V4 } & $\mathrm{C} 02$ & $\begin{array}{l}\text { Phormidium autumnale } \\
\text { Oscillatoriophycideae }\end{array}$ & EF654084 & 93.2 & 32 & 0 & 0 & 0 & 0 & 0 & 32 \\
\hline & & $\mathrm{C} 03$ & $\begin{array}{l}\text { Microcoleus antarcticus } \\
\text { Oscillatoriophycideae }\end{array}$ & AF218373 & 99.5 & 181 & 0 & 0 & 1 & 0 & 1 & 183 \\
\hline & & C04 & $\begin{array}{l}\text { Microcoleus rushforthii } \\
\text { Oscillatoriophycideae }\end{array}$ & AF218377 & 99.0 & 478 & 34 & 0 & 0 & 0 & 19 & 531 \\
\hline & & $\mathrm{C} 05$ & $\begin{array}{l}\text { Microcoleus vaginatus } \\
\text { Oscillatoriophycideae }\end{array}$ & EF654072 & 99.7 & 203 & 16 & 0 & 0 & 0 & 0 & 219 \\
\hline & & C06 & $\begin{array}{l}\text { Phormidium autumnale } \\
\text { Oscillatoriophycideae }\end{array}$ & EF654084 & 98.1 & 9 & 0 & 0 & 0 & 0 & 0 & 9 \\
\hline & & $\mathrm{C} 07$ & $\begin{array}{l}\text { Pseudophormidium } \\
\text { Oscillatoriophycideae }\end{array}$ & AY493587 & 97.6 & 0 & 1 & 0 & 1 & 0 & 0 & 2 \\
\hline & & $\mathrm{C} 08$ & $\begin{array}{c}\text { Chamaesiphon } \\
\text { subglobosusSynechococcales }\end{array}$ & AY170472 & 97.4 & 1 & 4 & 0 & 0 & 0 & 0 & 5 \\
\hline & & C09 & $\begin{array}{l}\text { Uncultured cyanobacterium } \\
\text { (from Rocky Mountains) }\end{array}$ & EF522318 & 98.6 & 22 & 0 & 0 & 0 & 0 & 0 & 22 \\
\hline & & $\mathrm{C} 10$ & $\begin{array}{l}\text { Uncultured cyanobacterium } \\
\text { (from Spanish stromatolites) }\end{array}$ & EU753634 & 98.6 & 8 & 1 & 0 & 0 & 0 & 0 & 9 \\
\hline & & C11 & $\begin{array}{l}\text { Leptolyngbya atarctica } \\
\text { Synechococcales }\end{array}$ & AY493572 & 99.5 & 0 & 2 & 0 & 0 & 0 & 0 & 2 \\
\hline & & $\mathrm{C} 12$ & $\begin{array}{l}\text { Phormidium sp. } \\
\text { Oscillatoriophycideae }\end{array}$ & AF076159 & 98.6 & 7 & 3 & 0 & 0 & 0 & 4 & 14 \\
\hline & & $\mathrm{C} 13$ & $\begin{array}{l}\text { Stenomitos tremulus } \\
\text { Synechococcales }\end{array}$ & AF218371 & 94.6 & 0 & 2 & 0 & 0 & 0 & 0 & 2 \\
\hline & & $\mathrm{C} 14$ & $\begin{array}{c}\text { Microcoleus glaciei } \\
\text { Oscillatoriophycideae }\end{array}$ & AF218374 & 96.9 & 6 & 2 & 0 & 0 & 0 & 2 & 10 \\
\hline & & C15 & $\begin{array}{c}\text { Microcoleus glaciei } \\
\text { Oscillatoriophycideae }\end{array}$ & AF218374 & 97.2 & 8 & 2 & 0 & 0 & 0 & 0 & 10 \\
\hline & & C16 & $\begin{array}{c}\text { Wilmottia murrayi } \\
\text { Oscillatoriophycideae }\end{array}$ & DQ493872 & 98.8 & 34 & 0 & 0 & 0 & 0 & 0 & 34 \\
\hline & & $\mathrm{C} 17$ & $\begin{array}{l}\text { Crinalium epipsammum } \\
\text { Oscillatoriophycideae }\end{array}$ & AB115965 & 98.6 & 17 & 18 & 1 & 4 & 17 & 0 & 57 \\
\hline & & $\mathrm{C} 18$ & $\begin{array}{c}\text { Chroococcidiopsis } \\
\text { Chroococcidiopsidales }\end{array}$ & DQ914863 & 96.0 & 0 & 0 & 0 & 0 & 4 & 0 & 4 \\
\hline & & C19 & $\begin{array}{l}\text { Uncultured cyanobacterium } \\
\text { (from Antarctic Peninsula) }\end{array}$ & FR749806 & 99.3 & 0 & 4 & 6 & 0 & 4 & 0 & 14 \\
\hline & & $\mathrm{C} 20$ & $\begin{array}{l}\text { Uncultured cyanobacterium } \\
\text { (from Antarctic Peninsula) }\end{array}$ & FR749806 & 98.8 & 1 & 2 & 0 & 0 & 0 & 0 & 3 \\
\hline & & $\mathrm{C} 21$ & $\begin{array}{l}\text { Uncultured cyanobacterium } \\
\text { (from Antarctic Dry Valleys) }\end{array}$ & HQ189092 & 95.7 & 0 & 2 & 6 & 0 & 2 & 0 & 10 \\
\hline & & $\mathrm{C} 22$ & $\begin{array}{l}\text { Uncultured cyanobacterium } \\
\text { (from Spanish stromatolites) }\end{array}$ & EU753646 & 96.7 & 27 & 0 & 0 & 0 & 0 & 0 & 27 \\
\hline & & $\mathrm{C} 23$ & $\begin{array}{l}\text { Uncultured cyanobacterium } \\
\text { (from Spanish stromatolites) }\end{array}$ & EU753646 & 97.2 & 26 & 0 & 0 & 0 & 0 & 0 & 26 \\
\hline & & $\mathrm{C} 24$ & Toxopsis calypsus Nostocales & JN695681 & 96.7 & 91 & 11 & 0 & 0 & 0 & 0 & 102 \\
\hline & & $\mathrm{C} 25$ & Tolypothrix sp. Nostocales & HG970654 & 98.6 & 0 & 5 & 7 & 0 & 0 & 0 & 12 \\
\hline & & $\mathrm{C} 26$ & Toxopsis calypsus Nostocales & JN695681 & 98.6 & 76 & 26 & 0 & 0 & 0 & 0 & 102 \\
\hline & & $\mathrm{C} 27$ & Nostoc carneum Nostocales & AB325906 & 98.1 & 4 & 0 & 0 & 0 & 0 & 0 & 4 \\
\hline & & $\mathrm{C} 28$ & Nostoc flagelliforme Nostocales & EU178143 & 98.6 & 8 & 1 & 3 & 0 & 0 & 1 & 13 \\
\hline & & $\mathrm{C} 29$ & Stigonema ocellatum Nostocales & AJ544082 & 97.9 & 31 & 0 & 0 & 0 & 0 & 0 & 31 \\
\hline & & \multicolumn{2}{|c|}{ Cyanobacterial total } & \multicolumn{2}{|c|}{29 phylotypes } & 1270 & 136 & 23 & 6 & 27 & 28 & 1490 \\
\hline & \multicolumn{3}{|c|}{ Overall total } & \multicolumn{2}{|c|}{57 phylotypes } & 22,885 & 6006 & 10,745 & 8137 & 14,463 & 54,701 & 116,937 \\
\hline
\end{tabular}

Phylotypes were affiliated with the most closely related sequences/organisms. Phylotypes were grouped at a $97 \%$ similarity cutoff value for near full-length 18S rRNA genes (18S) and eukaryotic ITS regions of lichen-forming fungi and algae, and near full-length 16S rRNA genes (16S) and partial V3-V4 region of 16S rRNA genes of algae-derived chloroplasts and cyanobacteria.

Based on the traditional Sanger-sequenced 18S and 16S rRNA genes and the ITS regions, all lichens except sample 3-2 showed bipartite fungal-algal Umbilicaria-Trebouxia partnerships (Table 4). Multiple phylotypes per sample were detected on the fungal side, in contrast to a single phylotype (from a single sequence) on the algal side, suggesting that partnerships are established with a specific photobiont. In contrast, sample 3-2 showed tripartite fungal-algal-cyanobacterial partnerships such as Umbilicaria-Trebouxia/Coccomyxa-Leptolyngbya (Table 4), with one genus (composed of six phylotypes) on the fungal side and two genera (composed of three phylotypes from nine sequences) on the algal side, suggesting plasticity in partnerships. These relationships appeared more plastic when viewed based on the V3-V4 sequences. Even the least plastic sample 2-2 with four fungal, one algal, and three 
cyanobacterial phylotypes (total of seven members) yielded eight chloroplast phylotypes (Table 4). One algal partner for a fungus may not necessarily mean a fixed specific partnership, considering that chloroplast diversity may contribute to the enhanced adaptability of the chloroplast-hosting algae as well as the algae-hosting lichens [66]. However, this result is based only on the six samples of a single lichen genus Umbilicaria from limited area coverage and, thus, should not be extended to lichens in other taxa or habitats.

\subsubsection{Fungal Phylotypes}

Fungal phylotypes were affiliated with four species of Umbilicaria, the representative genus of the rock tripe lichens (Tables 3 and 4; Figure 3). Three $18 \mathrm{~S}$ rRNA gene-based phylotypes (referred to as 18S-based phylotypes from hereinafter) were the most closely related to U. rhizinata (only in the sample 3-2), which occur predominantly on the high mountains such as the Himalayas and on the King George Island in the maritime Antarctic $[67,68]$. The other 18S-based phylotype was related to $U$. decussate (in all samples), which is known to occur in East Antarctica [69].
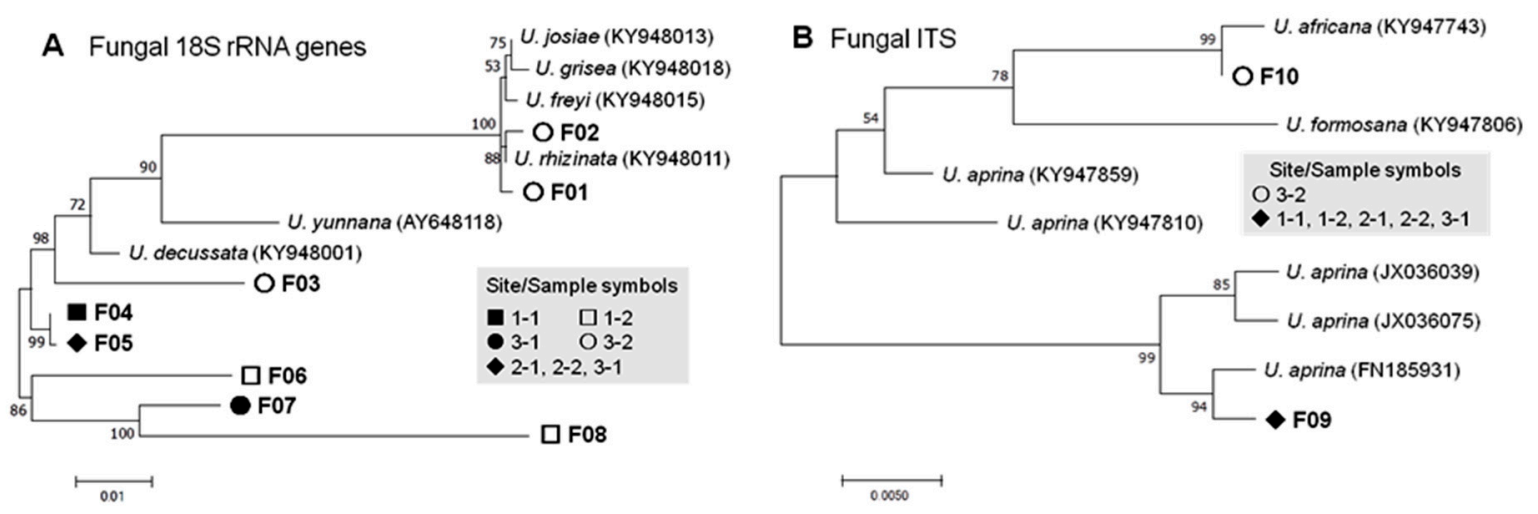

Figure 3. Phylogenetic trees of $18 \mathrm{~S}$ rRNA genes (A) and ITS regions (B) of the lichen-forming fungal phylotypes and related Umbilicaria species (with accession numbers) generated by the Maximum Composite Likelihood method. The tree with the highest log likelihoods $(-3645.00$ and -896.60 for A and $\mathrm{B}$, respectively) is shown. The percentage of trees in which the associated taxa clustered together is shown next to the branches. The tree is drawn to scale, with branch lengths measured in the number of substitutions per site. Phylotype codes correspond to those shown in Table 4.

The ITS-based phylotypes were the most closely related to the Iranian strain of $U$. aprina [70] and probably an Afro-Eurasian strain of $U$. africana [71]; both species were recorded as lichens in East Antarctica [72,73]. Usually the ITS regions and rRNA genes of different fungal species are variably amplified by PCR [74], which is likely the case in this study.

\subsubsection{Algal Phylotypes}

The 18S-based algal phylotypes were affiliated primarily with a Coccomyxa viridis strain, which was isolated in a free-living form from wet sandstone in Germany [75], and with the strain Trebouxia sp. SAG 246, which was maintained at the Culture Collection of Algae at the University of Göttingen (SAG, Germany) but is currently not available in the SAG Catalogue (https://sagdb.uni-goettingen.de/). Both the phylotypes were detected only in sample 3-2 (Tables 3 and 4; Figure 4). 

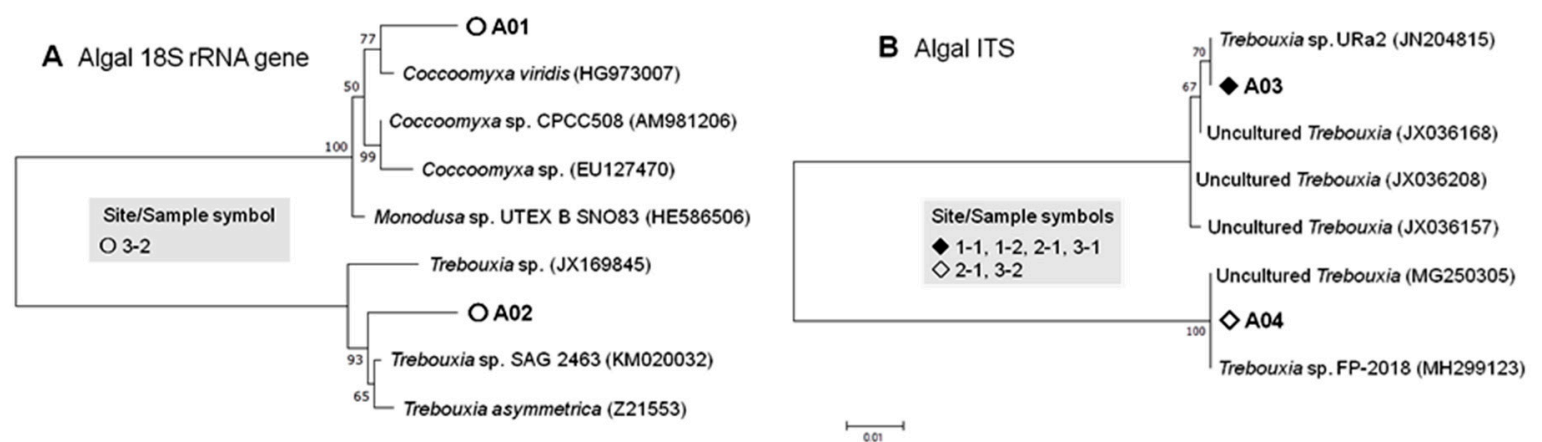

$\stackrel{\longmapsto}{0.005}$

Figure 4. Phylogenetic trees of 18S rRNA genes (A) and ITS regions (B) of the lichen-associated algal phylotypes and related green algal species (with accession numbers) generated by the Maximum Composite Likelihood method. The tree with the highest log likelihoods ( -3335.88 and -1105.35 for A and $\mathrm{B}$, respectively) is shown. The percentage of trees in which the associated taxa clustered together is shown next to the branches. The tree is drawn to scale, with branch lengths measured in the number of substitutions per site. Phylotype codes correspond to those shown in Table 4.

The ITS-based phylotypes were affiliated with Trebouxia sp. URa2, which was recorded as a photobiont of the lecideoid lichen Lecidea andersonii in Queen Maud Land, East Antarctica [26] and with Trebouxia sp. FP-2018, hosted by the presumed Mediterranean-endemic lichen Lasallia hispanica [9]. The phylotype related to Trebouxia sp. URa2 was found only in samples 1-1, 1-2, 2-1, and 2-2, which were collected from areas 1 and 2, i.e., Langhovde Hills and Skarvsnes Foreland, respectively. On the other hand, the phylotype related to Trebouxia sp. FP-2018 was found only in samples 3-1 and 3-2 from area 3, Skallen Hills. It is not clear whether the separate distribution was due to the local biogeography or coincidental methodical sample-to-sample variation.

An Antarctic-wide survey showed 141 ITS-based algal phylotypes, all affiliated with the genus Trebouxia, from 12 saxicolous lecideoid lichen species [26]. In contrast, three Trebouxia and one Coccomyxa phylotypes from 10 Umbilicaria phylotypes were found in this study. The low algal diversity might be because of the narrow area coverage resulting in less diverse geographic features and to the nature of the Umbilicaria mycobionts.

\subsubsection{Chloroplast Phylotypes}

Chloroplast phylotypes were affiliated only loosely with those hosted by 10 green algal genera, mostly (nine genera) within the class Trebouxiophyceae, but one (T03; Ettlia) affiliated at an 87.6\% similarity with the class Chlorophyceae (Tables 3 and 4; Figure 5). The highest similarity of $97.7 \%$ was seen for T11 with the chloroplast of Chloroidium saccharophilum, a known lichen-hosted green alga [76]. Chloroplasts of the green alga Coccomyxa were related mostly to the phylotypes from the sample 3-2, along with a few incidences in the sample 2-2 (Table 4). Another green algal host genus Trebouxia was found in all the samples in this study; however, no Trebouxia-affiliated phylotypes of chloroplast were detected, probably because of the relative lack of registered chloroplast 16S rRNA gene sequences of the Trebouxia species [77]. Additionally, we can speculate that the lineages of Trebouxia-hosted chloroplast might have been so diverged that they would be affiliated differently.

Most of the 16S rRNA gene-based phylotypes (hereinafter 16S-based phylotypes) were found in samples 2-2, 3-1, and 3-2; and none in sample 1-1. In contrast, sample 1-1 yielded the second largest number of V3-V4 sequences, T12, affiliated at a 92.8\% similarity with the chloroplast of the green alga Neglectella solitaria in the class Trebouxiophyceae [78]. The majority of the overall sequences $(115,407$ against 117,027$)$ were generated from this single phylotype, T12, which was eminently found in all the samples; samples from site 3-2 yielded the largest number. The occurrence of N. solitaria, formerly Oocystis solitaria, in Antarctica has not been archived till date [79], and it is not a recognized photobiont of Umbilicaria and other lichens. It should be noted that the phylotype T12, despite the 
affiliation with N. solitaria, is most likely hosted by Trebouxia or Coccomyxa. Genotypic inventory of microalgal chloroplasts [66] is needed to identify the Trebouxia or Coccomyxa chloroplasts that have phylotypic affiliation with Neglectella, along with the incoherent phylogenetic positions of the few known Trebouxia-chloroplasts (Figure 5).
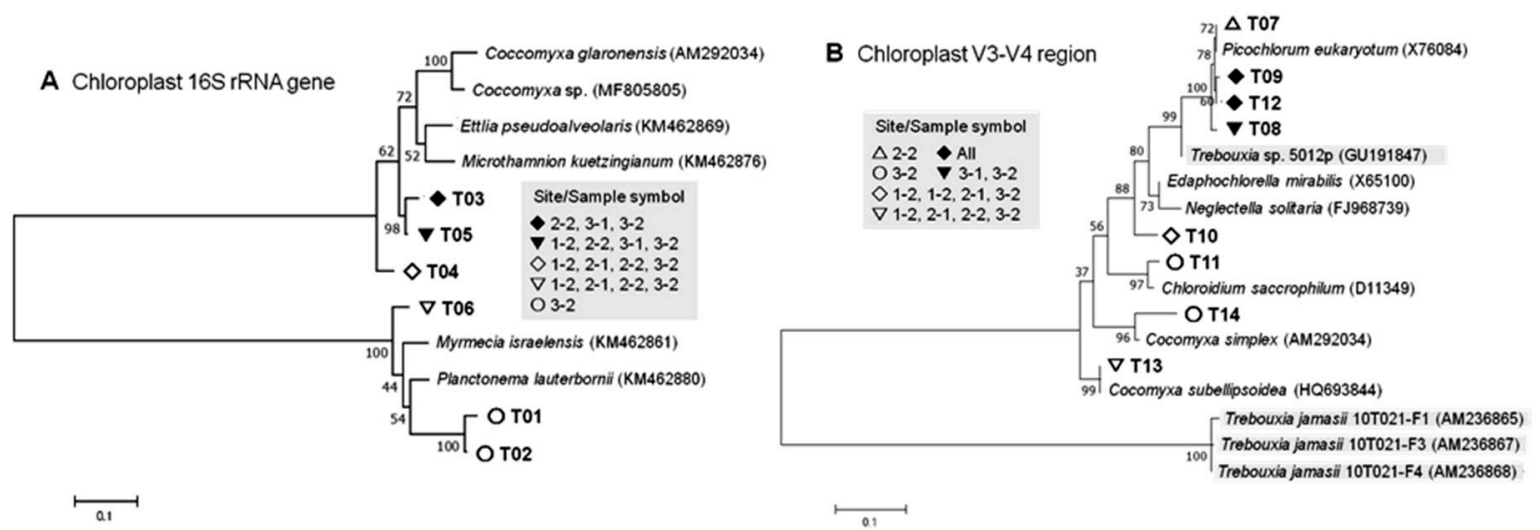

Figure 5. Phylogenetic trees of 16S rRNA genes (A) and V3-V4 regions (B) of the lichen-associated algae-derived and related chloroplast phylotypes (with accession numbers) generated by the Maximum Composite Likelihood method. The tree with the highest log likelihoods ( -6819.36 and -1396.40 for A and B, respectively) is shown. Four known Trebouxia-hosted chloroplast sequences are lightly shaded. The percentage of trees in which the associated taxa clustered together is shown next to the branches. The tree is drawn to scale, with branch lengths measured in the number of substitutions per site. Phylotype codes correspond to those shown in Table 4.

Other dominant non-Trebouxia/Coccomyxa-affiliated chloroplast phylotypes, T09 and T05, were affiliated with those of Edaphochlorella mirabilis and Myrmecia israelensis at a similarity of $92.1 \%$ and $88.3 \%$, respectively (Table 4). Occurrences of both species in Antarctica has not yet been known [79], however $M$. israelensis is known to serve as a photobiont of the rock-dwelling Verrucariaceae lichens [80]. However, considering the low similarity values, further phylogenetic discussion might not be meaningful.

The discrepancy between the Sanger- and MiSeq-sequencing for lichen photobionts has multiple causes [9], such as differences in target sequences, primers, cloning protocol, sequencing methods, assembly protocols, alignment algorithms, and databases, which are categorized as artifacts. The biological factors for non-detection of Trebouxia-affiliated chloroplast phylotypes may be caused by the diverged lineages of the chloroplast, although it is highly speculative that "chloroplast switching" (which resembles "photobiont switching," a fungal strategy to increase adaptability of a lichen to an ever-changing environment [24,25]) is hypothesized for the host algae.

\subsubsection{Cyanobacterial Phylotypes}

Only one 16S-based cyanobacterial phylotype was detected in sample 3-2 and affiliated with Leptolyngbya antarctica (Table 4), which is non-endemic to Antarctic but is widespread in the continent in a free-living form [81]. The occurrence of L. antarctica, formerly known as Phormidium antarcticum, in the ASPA 141 Yukidori Valley, which corresponds to site 1-1 in this study, was also reported [82]. Another L. antarctica-affiliated phylotype, based on the V3-V4 sequence (Table 4; Figure 6), was found in the sample from site 1-2. However, no L. antarctica-affiliated V3-V4 phylotype was detected in the sample from site 1-1, which may suggest that $L$. antarctica may be involved in lichen-formation or lichen-association as an opportunistic bystander. The same interpretation would hold true for other cyanobacteria, considering their airborne dispersibility in the Antarctic [83]. 


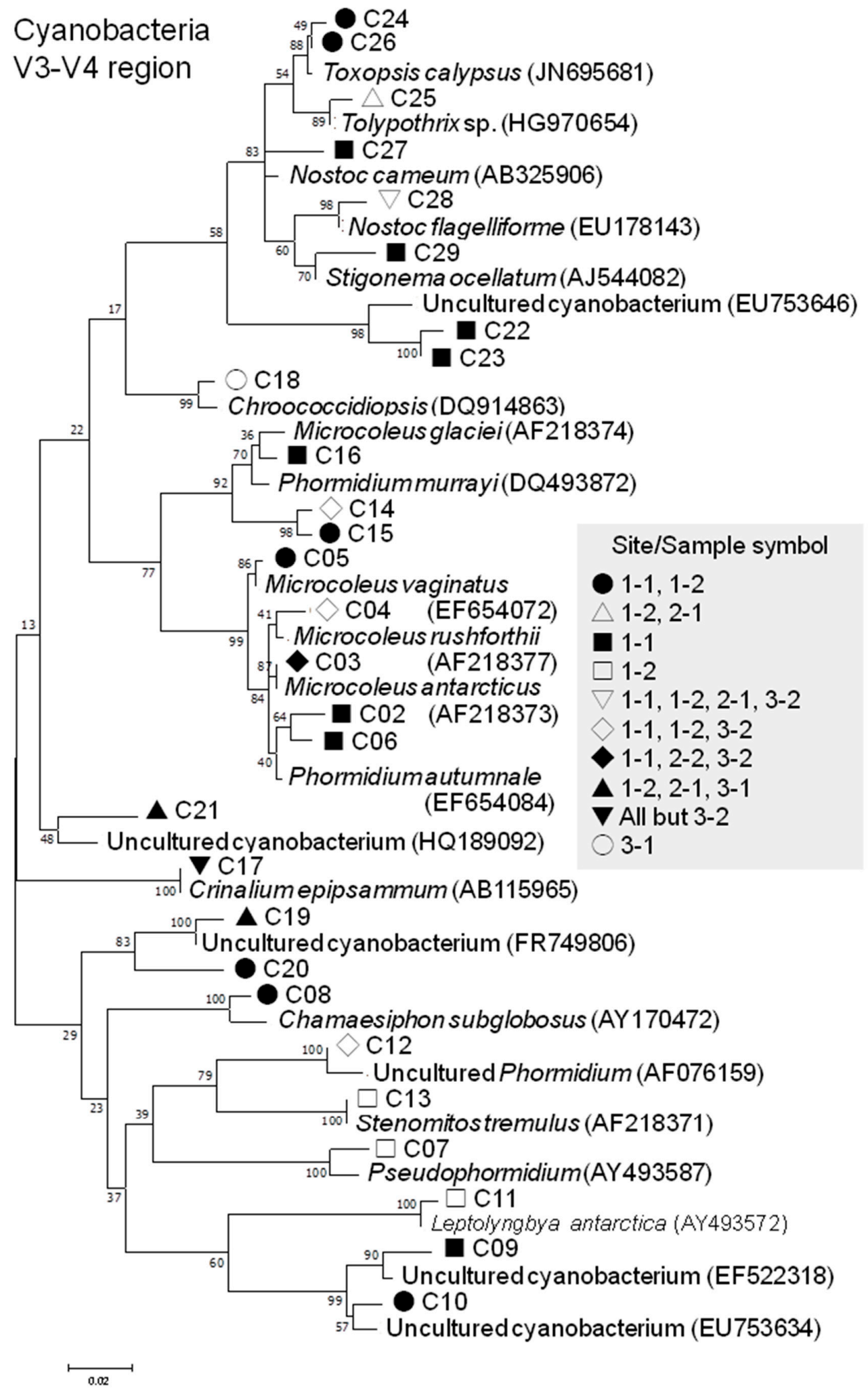

Figure 6. Phylogenetic trees of V3-V4 regions of 16S rRNA gene of the lichen-associated cyanobacterial phylotypes (with accession numbers) generated by the Maximum Composite Likelihood method. The tree with the highest log likelihoods $(-3441.61)$ is shown. The percentage of trees in which the associated taxa clustered together is shown next to the branches. The tree is drawn to scale, with branch lengths measured in the number of substitutions per site. Phylotype codes correspond to those shown in Table 4. 
Nostoc is generally the most commonly known cyanobacterial genus in lichens [84], and two Nostoc-affiliated phylotypes (C27 and C28) were detected in Umbilicaria lichens in this study. However, the two phylotypes consisted only of 17 sequences, compared with a total of 1490 cyanobacterial sequences (Table 4). The largest number, 953, of the sequences constituted five phylotypes (C03-C05, C14, and C15) affiliated with four Microcoleus species: M. antarcticus, M. rushforthii, and M. glaciei of the Antarctic origin [85], along with M. vaginatus of which its occurrence in Antarctica has not been recorded yet. It should be noted that $M$. vaginatus occurs in the Arctic Spitsbergen [86] and its phylotypes phylotypes from the substrate of lichens in Navarino Island, the southernmost island of Chile [87], was reported, and its role in the formation of biological soil crust which eventually leads to contact with lichens is well known [88]. Therefore, their predominance in the Umbilicaria lichens in this study, particularly in the sample from site 1-1, is notable and may be considered as aiding in providing certain ecological and biogeochemical roles in the lichen and ambient systems. Their predominance as lichen-forming or lichen-associated cyanobacteria would increase the scientific value of the region and the need of monitoring the ASPA 141 Yukidori Valley.

The second most abundant affiliated species was Toxopsis calypsus (with the phylotypes C24 and C26), which represents the newly proposed genus and species in 2012, based on a culture from a Greek cave [89]. A phylotype affiliated with Toxopsis was found to be abundant in the inland soils of East Antarctica, and its association with moss and lichens was suggested [90].

\subsection{Phylotypic Profiles of the Studied Samples}

The rock tripe lichen samples in this study were collected from three areas over a $50 \mathrm{~km}$ range (Langhovde, Skarvsnes, and Skallen, depicted in Figure 1) but were analyzed as one-sample-per-site $(n=1)$ and, thus, do not statistically represent the biogeographic features of the sites.

As stated above, samples 3-1 and 1-1 were distinctly unique in the predominant occurrences of the chloroplast phylotypes affiliated with those of the Neglectella solitaria and other green algae and the Microcoleus-affiliated cyanobacterial phylotypes, respectively. These phylotypes, as well as the living specimens, have rarely been recorded in East Antarctica, or whole Antarctica, however they were massively detected by the V3-V4-targetted MiSeq, high-throughput sequencing.

Heatmaps were generated to encompass dendrograms by cluster analysis of the phylotype compositions of chloroplasts and cyanobacteria (Figure 7). The dendrograms revealed the uniqueness of samples 3-2 and 1-1 in the phylotype compositions of chloroplasts and cyanobacteria, respectively. Heatmaps roughly aid in the visualization of the phylotypes contributing to the sample uniqueness (Figure 7). For chloroplast phylotypes, sample 3-2 was characterized by yielding 13/14 chloroplast phylotypes as well as the largest number of V3-V4 sequences of chloroplasts, with the most abundant phylotype T12 (affiliated at a 92.8\% similarity with the chloroplast of Neglectella solitaria; Table 4). For cyanobacteria, sample 1-1 was characterized by yielding 21/28 cyanobacterial phylotypes as well as the largest number of cyanobacterial V3-V4 sequences, with five abundant phylotypes C03, C04, C05, C14, and C15 (affiliated at $>96.9 \%$ similarities with the genus Microcoleus; Table 4). Because the Microcoleus cyanobacteria may have ecological and biogeochemical functions as stated above, sample 1-1 might represent a hotspot of lichen-microbial interactions. 

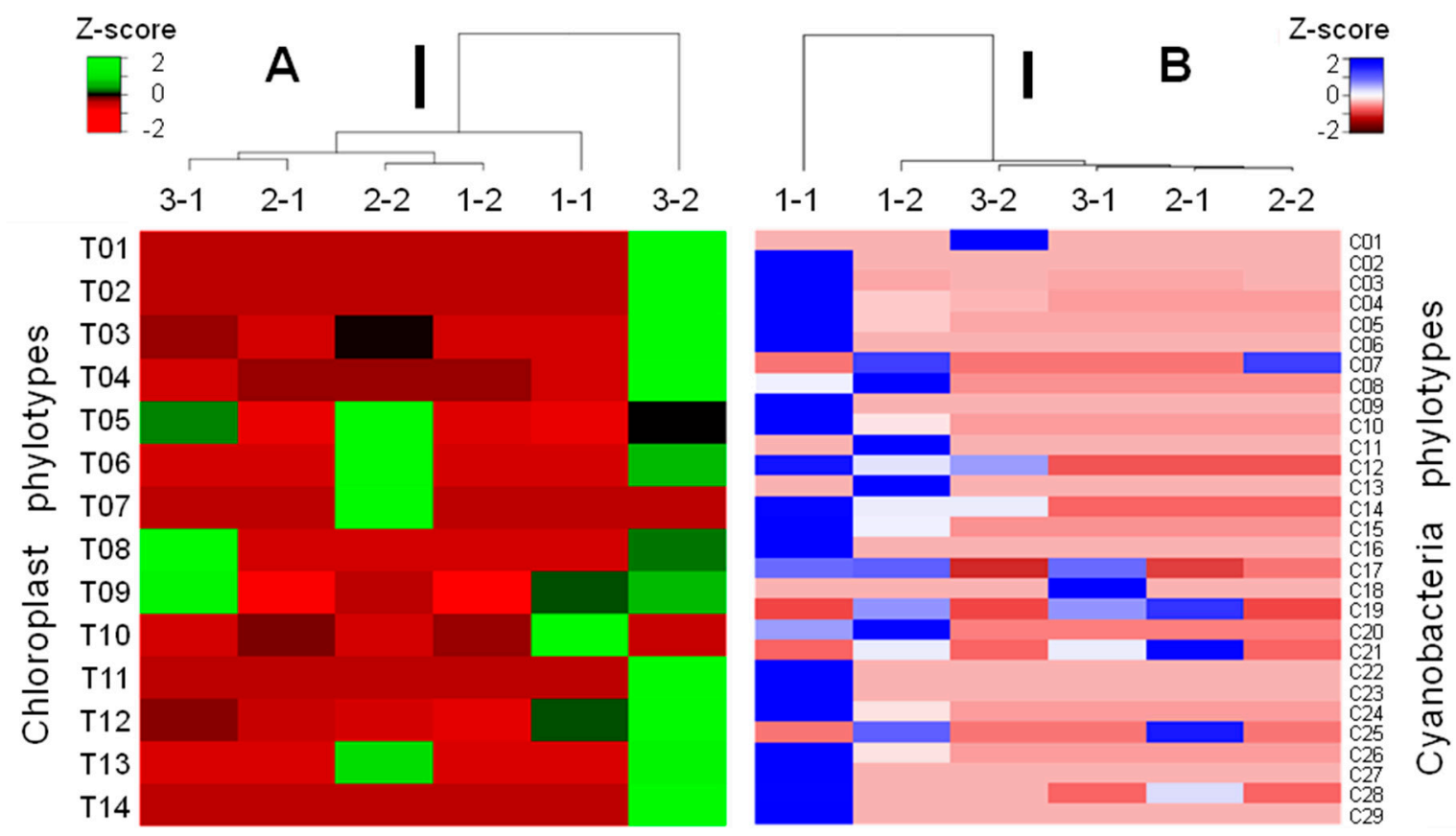

Figure 7. Heatmaps encompassing dendrograms of cluster-analyzed lichen samples based on the phylotype compositions of algae-derived chloroplasts (A) and lichen-associated cyanobacteria (B). The uniqueness of samples 3-2 and 1-1 is caused by predominant occurrences of specific phylotypes of chloroplast and cyanobacteria, respectively. Phylotype codes correspond to those shown in Table 4 . Thick bars beside dendrograms indicate Euclidean distances of the dendrograms as 2000 (A) and 200 (B).

\section{Conclusions}

In the rock tripe Umbilicaria lichens from narrow-ranged sites in East Antarctica, unexpected diversities in the green algal chloroplasts and cyanobacteria were observed. Chloroplast phylotypes were predominated not by the lichen-hosted green algal (Trebouxia and Coccomyxa) chloroplasts, but by those affiliated with less common green algal chloroplasts, suggesting cryptic diversity inside the microalgal single cells. Cyanobacterial phylotypes of a single sample from an Antarctic Specially Protected Area were dominated not by the common lichen partner Nostoc, but by the uncommon Microcoleus. The occurrence of these less common lichen-forming components may contribute to phenotypic, as well as genotypic, variability within the rock tripe lichen photobionts.

Supplementary Materials: Supplementary materials can be found at http://www.mdpi.com/2076-2607/7/7/203/s1.

Author Contributions: M.S.F. performed the DNA extraction/sequencing and bioinformatic analyses, and prepared the manuscript. R.N. supported the bioinformatic analyses and reviewed/edited the manuscript. S.I. supported sample collection and manuscript preparation. T.N. planned the study, performed sample collection, and reviewed/edited the manuscript.

Funding: This study was supported by Japan Society for the Promotion of Science (JSPS) KAKENHI Grant Number JP16H05765 and by the National Institute of Polar Research (NIPR) of Japan through General Collaboration Project nos. 26-42 and 29-28.

Acknowledgments: The authors are obliged to thank the 52nd Japanese Antarctic Research Expedition, supported by NIPR under Ministry of Education, Culture, Sports, Science and Technology of Japan, for the opportunity to collect the lichen samples used in this study. Katsuhiko Kashihara and Ayaka Ohsato contributed to the Sanger-sequencing and MiSeq-sequencing of this study. The authors are grateful to the anonymous reviewers who provided valuable and constructive comments to improve the manuscript. The authors would like to thank Editage (www.editage.com) for English language editing.

Conflicts of Interest: The authors declare no conflict of interest. 


\section{References}

1. Kirk, P.M.; Cannon, P.F.; Minter, D.W.; Stalpers, J.A. Dictionary of the Fungi, 10th ed.; CABI: Wallingford, UK, 2008; p. 378. ISBN 978-0851998268.

2. Friedl, T.; Büdel, B. Photobionts. In Lichen Biology, 2nd ed.; Nash, T.H., III, Ed.; Cambridge University Press: Cambridge, UK, 2012; pp. 9-26.

3. Tschermak-Woess, E. The algal partner. In Handbook of Lichenology; Galun, M., Ed.; CRC Press: Boca Raton, FL, USA, 1988; Volume 1, pp. 39-92. ISBN 978-0849335815.

4. Suryanarayanan, T.S.; Thirunavukkarasu, N. Endolichenic fungi: The lesser known fungal associates of lichens. Mycology 2017, 8, 189-196. [CrossRef] [PubMed]

5. Maduranga, K.; Attanayake, R.N.; Santhirasegaram, S.; Weerakoon, G.; Paranagama, P.A. Molecular phylogeny and bioprospecting of Endolichenic Fungi (ELF) inhabiting in the lichens collected from a mangrove ecosystem in Sri Lanka. PLoS ONE 2018, 13, e0200711. [CrossRef] [PubMed]

6. Lawrey, J.D.; Diederich, P. Lichenicolous fungi: Interactions, evolution, and biodiversity. Bryologist 2003, 106, 80-120. [CrossRef]

7. Spribille, T.; Tuovinen, V.; Resl1, P.; Vanderpool, D.; Wolinski, H.; Aime, M.C.; Schneider, K.; Stabentheiner, E.; Toome-Heller, E.; Thor, G.; et al. Basidiomycete yeasts in the cortex of ascomycete macrolichens. Science 2016, 353, 488-492. [CrossRef] [PubMed]

8. Tuovinen, V.; Ekman, S.; Thor, G.; Vanderpool, D.; Spribille, T.; Johannesson, H. Two basidiomycete fungi in the cortex of wolf lichens. Curr. Biol. 2019, 29, 476-483. [CrossRef] [PubMed]

9. Paul, F.; Otte, J.; Schmitt, I.; Dal Grande, F. Comparing Sanger sequencing and high-throughput metabarcoding for inferring photobiont diversity in lichens. Sci. Rep. 2018, 8, 8624. [CrossRef]

10. Farrar, J.F. Lichen as an ecosystem: Observation and experiment. In Lichenology: Progress and Problems; Brown, D.H., Hawksworth, D.L., Bailey, R.H., Eds.; Academic Press: London, UK, 1976; pp. 385-406. ISBN 978-0121367503.

11. Parasyri, A.; Papazi, A.; Stamatis, N.; Zerveas, S.; Avramidou, E.V.; Doulis, A.G.; Pirintsos, S.; Kotzabasis, K. Lichen as micro-ecosystem: Extremophilic behavior with astrobiotechnological applications. Astrobiology 2018, 18, 1528-1542. [CrossRef]

12. Richardson, D.H.S. War in the world of lichens: Parasitism and symbiosis as exemplified by lichens and lichenicolous fungi. Mycol. Res. 1999, 103, 641-650. [CrossRef]

13. Wedin, M.; Maier, S.; Fernandez-Brime, S.; Cronholm, B.; Westberg, M.; Grube, M. Microbiome change by symbiotic invasion in lichens. Environ. Microbiol. 2016, 18, 1428-1439. [CrossRef]

14. Haas, J.R.; Purvis, O.W. Lichen biogeochemistry. In Fungi in Biogeochemical Cycles; Gadd, G.M., Ed.; Cambridge University Press: Cambridge, UK, 2006; pp. 344-376.

15. Lange, O.L.; Green, T.G.A. Lichens show that fungi can acclimate their respiration to seasonal changes in temperature. Oecologia 2005, 142, 11-19. [CrossRef]

16. Gauslaa, Y.; Lie, M.; Solhaug, K.A.; Ohlson, M. Growth and ecophysiological acclimation of the foliose lichen Lobaria pulmonaria in forests with contrasting light climates. Oecologia 2006, 147, 406-416. [CrossRef]

17. Pérez-Ortega, S.; Fernández-Mendoza, F.; Raggio, J.; Vivas, M.; Ascaso, C.; Sancho, L.G.; Printzen, C.; de Los Ríos, A. Extreme phenotypic variation in Cetraria aculeata (lichenized Ascomycota), adaptation or incidental modification? Ann. Bot. 2012, 109, 1133-1148. [CrossRef]

18. Printzen, C.; Domaschke, S.; Fernández-Mendoza, F.; Pérez-Ortega, S. Biogeography and ecology of Cetraria aculeata, a widely distributed lichen with a bipolar distribution. MycoKeys 2013, 6, 33-53. [CrossRef]

19. Piercey-Normore, M.D.; Depriest, P.T. Algal switching among lichen symbioses. Am. J. Bot. 2001, 88, 1490-1498. [CrossRef]

20. Piercey-Normore, M.D. Selection of algal genotypes by three species of lichen fungi in the genus Cladonia. Can. J. Bot. 2004, 82, 947-961. [CrossRef]

21. Blaha, J.; Baloch, E.; Grube, M. High photobiont diversity associated with the euryoecious lichen-forming ascomycete Lecanora rupicola (Lecanoraceae, Ascomycota). Biol. J. Linnean Soc. 2006, 88, 283-293. [CrossRef]

22. Yahr, R.; Vilgalys, R.; Depriest, P.T. Geographic variation in algal partners of Cladonia subtenuis (Cladoniaceae) highlights the dynamic nature of a lichen symbiosis. New Phytol. 2006, 171, 847-860. [CrossRef] 
23. Castello, M.; Nimis, P. Diversity of lichens in Antarctica. In Antarctic Communities: Species, Structure and Survival; Valencia, J., Walton, D.W.H., Battaglia, B., Eds.; Cambridge University Press: Cambridge, UK, 2009; pp. 15-21. ISBN 978-0-521-11179-9.

24. Green, T.G.A.; Lange, O.L. Photosynthesis in poikilohydric plants: A comparison of lichens and bryophytes. In Ecophysiology of Photosynthesis, Springer Study Edition, Volume 100; Schultze, E.-D., Caldwell, M.M., Eds.; Springer: Berlin/Heidelberg, Germany, 1995; pp. 319-341.

25. Sancho, L.G.; Pintado, A.; Green, T.G.A. Antarctic studies show lichens to be excellent biomonitors of climate change. Diversity 2019, 11, 42. [CrossRef]

26. Ruprecht, U.; Brunauer, G.; Printzen, C. Genetic diversity of photobionts in Antarctic lecideoid lichens from an ecological view point. Lichenologist 2012, 44, 661-678. [CrossRef]

27. Cardinale, M.; Puglia, A.M.; Grube, M. Molecular analysis of lichen-associated bacterial communities. FEMS Microbiol. Ecol. 2006, 57, 484-495. [CrossRef]

28. Grube, M.; Cardinale, M.; de Castro, J.V., Jr.; Müller, H.; Berg, G. Species-specific structural and functional diversity of bacterial communities in lichen symbioses. ISME J. 2009, 3, 1105-1115. [CrossRef]

29. Bates, S.T.; Cropsey, G.W.; Caporaso, J.G.; Knight, R.; Fierer, N. Bacterial communities associated with the lichen symbiosis. Appl. Environ. Microbiol. 2011, 77, 1309-1314. [CrossRef]

30. Cernava, T.; Berg, G.; Grube, M. High life expectancy of bacteria on lichens. Microb. Ecol. 2016, 72, 510-513. [CrossRef]

31. Miller, D.N.; Bryant, J.E.; Madsen, E.L.; Ghiorse, W.C. Evaluation and optimization of DNA extraction and purification procedures for soil and sediment samples. Appl. Environ. Microbiol. 1999, 65, 4715-4724.

32. Medlin, L.; Elwood, H.J.; Stickel, S.; Sogin, M.L. The characterization of enzymatically amplified eukaryotic 16S-like rRNA-coding regions. Gene 1998, 30, 491-499. [CrossRef]

33. Nakai, R.; Nakamura, K.; Jadoon, W.A.; Kashihara, K.; Naganuma, T. Genus-specific quantitative PCR of thraustochytrid protists. Mar. Ecol. Prog. Ser. 2013, 486, 1-12. [CrossRef]

34. Delong, E.F. Archaea in coastal marine environments. Proc. Natl. Acad. Sci. USA 1992, 89, 5685-5689. [CrossRef]

35. Amann, R.I.; Binder, B.J.; Olson, R.J.; Chisholm, S.W.; Devereux, R.; Stahl, D.A. Combination of $16 \mathrm{~S}$ rRNA-targeted oligonucleotide probes with flow cytometry for analyzing mixed microbial populations. Appl. Environ. Microbiol. 1990, 56, 1919-1925.

36. Gardes, M.; Bruns, T.D. ITS primers with enhanced specificity for basidiomycetes-application to the identification of mycorrhizae and rusts. Mol. Ecol. 1993, 2, 113-118. [CrossRef]

37. White, T.J.; Bruns, T.; Lee, S.; Taylor, J. Amplification and direct sequencing of fungal ribosomal RNA genes for phylogenetics. In PCR Protocols: A Guide to Methods and Applications; Innis, M.A., Gelfand, D.H., Sninsky, J.J., White, T.J., Eds.; Elsevier: Amsterdam, The Netherlands, 1990; pp. 315-322. [CrossRef]

38. Klindworth, A.; Pruesse, E.; Schweer, T.; Peplies, J.; Quast, C.; Horn, M.; Glöckner, F.O. Evaluation of general 16S ribosomal RNA gene PCR primers for classical and next-generation sequencing-based diversity studies. Nucleic Acids Res. 2013, 41, e1. [CrossRef]

39. Yergeau, E.; Bell, T.H.; Champagne, J.; Maynard, C.; Tardif, S.; Tremblay, J.; Greer, C.W. Transplanting soil microbiomes leads to lasting effects on willow growth, but not on the rhizosphere microbiome. Front. Microbiol. 2015, 6, 1436. [CrossRef]

40. Thompson, J.D.; Higgins, D.G.; Gibson, T.J. CLUSTAL W: Improving the sensitivity of progressive multiple sequence alignment through sequence weighting, position-specific gap penalties and weight matrix choice. Nucleic Acids Res. 1994, 22, 4673-4680. [CrossRef]

41. Hall, T.A. BioEdit: A user-friendly biological sequence alignment editor and analysis program for Windows 95/98/NT. Nucleic Acids Symp. Ser. 1999, 41, 95-98. [CrossRef]

42. Jumpponen, A. Soil fungal communities underneath willow canopies on a primary successional glacier forefront: rDNA sequence results can be affected by primer selection and chimeric data. Microb. Ecol. 2007, 53, 233-246. [CrossRef]

43. Li, W.; Godzik, A. Cd-hit: A fast program for clustering and comparing large sets of protein or nucleotide sequences. Bioinformatics 2006, 22, 1658-1659. [CrossRef]

44. Huang, Y.; Niu, B.F.; Gao, Y.; Fu, L.M.; Li, W.Z. CD-HIT Suite: A web server for clustering and comparing biological sequences. Bioinformatics 2010, 26, 680-682. [CrossRef] 
45. Altschul, S.F.; Madden, T.L.; Schaffer, A.A.; Zhang, J.; Zhang, Z.; Miller, W.; Lipman, D.J. Gapped BLAST and PSI-BLAST: A new generation of protein database search programs. Nucleic Acids Res. 1997, 25, 3389-3402. [CrossRef]

46. Aronesty, E. Comparisons of sequencing utility programs. Open Bioinform. J. 2013, 7, 1-8. [CrossRef]

47. Yoon, S.H.; Ha, S.M.; Kwon, S.; Lim, J.; Kim, Y.; Seo, H.; Chun, J. Introducing EzBioCloud: A taxonomically united database of $16 \mathrm{~S}$ rRNA gene sequences and whole-genome assemblies. Int. J. Syst. Evol. Microbiol. 2017, 67, 1613-1617. [CrossRef]

48. Pajarillo, E.A.; Chae, J.P.; Kim, H.B.; Kim, I.H.; Kang, D.K. Barcoded pyrosequencing-based metagenomic analysis of the faecal microbiome of three purebred pig lines after cohabitation. Appl. Microbiol. Biotechnol. 2015, 99, 5647-5656. [CrossRef]

49. Kim, J.Y.; Kim, E.M.; Yi, M.H.; Lee, J.; Lee, S.; Hwang, Y.; Yong, D.; Sohn, W.M.; Yong, T.S. Intestinal fluke Metagonimus yokogawai infection increases probiotic Lactobacillus in mouse cecum. Exp. Parasitol. 2018, 193, 45-50. [CrossRef]

50. Lee, B.; Moon, T.; Yoon, S.; Weissman, T. DUDE-Seq: Fast, flexible, and robust denoising for targeted amplicon sequencing. PLoS ONE 2017, 12, e0181463. [CrossRef]

51. Yarza, P.; Yilmaz, P.; Pruesse, E.; Glöckner, F.O.; Ludwig, W.; Schleifer, K.H.; Whitman, W.B.; Euzéby, J.; Amann, R.; Rosselló-Móra, R. Uniting the classification of cultured and uncultured bacteria and archaea using $16 \mathrm{~S}$ rRNA gene sequences. Nat. Rev. Microbiol. 2014, 12, 635-645. [CrossRef]

52. Edgar, R.C.; Haas, B.J.; Clemente, J.C.; Quince, C.; Knight, R. UCHIME improves sensitivity and speed of chimera detection. Bioinformatics 2011, 27, 2194-2200. [CrossRef]

53. Unno, T. Bioinformatic suggestions on MiSeq-based microbial community analysis. J. Microbiol. Biotechnol. 2015, 25, 765-770. [CrossRef]

54. Hammer, Ø.; Harper, D.A.T.; Ryan, P.D. PAST: Paleontological statistics software package for education and data analysis. Palaeontol. Electron. 2001, 4, 1-9.

55. Kumar, S.; Stecher, G.; Tamura, K. MEGA7: Molecular Evolutionary Genetics Analysis version 7.0 for bigger datasets. Mol. Biol. Evol. 2016, 33, 1870-1874. [CrossRef]

56. Tamura, K.; Nei, M.; Kumar, S. Prospects for inferring very large phylogenies by using the neighbor-joining method. Proc. Natl. Acad. Sci. USA 2004, 101, 11030-11035. [CrossRef]

57. Kimura, M. A simple method for estimating evolutionary rate of base substitutions through comparative studies of nucleotide sequences. J. Mol. Evol. 1980, 16, 111-120. [CrossRef]

58. Babicki, S.; Arndt, D.; Marcu, A.; Liang, Y.; Grant, J.R.; Maciejewski, A.; Wishart, D.S. Heatmapper: Web-enabled heat mapping for all. Nucleic Acids Res. 2016, 44, W147-W153. [CrossRef]

59. Konstantinidis, K.T.; Tiedje, J.M. Genomic insights that advance the species definition for prokaryotes. Proc. Natl. Acad. Sci. USA 2005, 102, 2567-2572. [CrossRef]

60. Nguyen, N.-P.; Warnow, T.; Pop, M.; White, B. A perspective on $16 \mathrm{~S}$ rRNA operational taxonomic unit clustering using sequence similarity. NPJ Biofilms Microbiom. 2016, 2, 16004. [CrossRef]

61. Mysara, M.; Vandamme, P.; Props, R.; Kerckhof, F.M.; Leys, N.; Boon, N.; Raes, J.; Monsieurs, P. Reconciliation between operational taxonomic units and species boundaries. FEMS Microbiol. Ecol. 2017, 93, fix029. [CrossRef]

62. Wu, S.; Xiong, J.; Yu, Y. Taxonomic resolutions based on $18 \mathrm{~S}$ rRNA genes: A case study of subclass Copepoda. PLoS ONE 2015, 10, e0131498. [CrossRef]

63. Nilsson, R.H.; Kristiansson, E.; Ryberg, M.; Hallenberg, N.; Larsson, K.-H. Intraspecific ITS variability in the kingdom Fungi as expressed in the international sequence databases and its implications for molecular species identification. Evol. Bioinform. 2008, 4, 193-201. [CrossRef]

64. Lindeque, P.K.; Parry, H.E.; Harmer, R.A.; Somerfield, P.J.; Atkinson, A. Next generation sequencing reveals the hidden diversity of zooplankton assemblages. PLoS ONE 2013, 8, e81327. [CrossRef]

65. Lemons, A.R.; Barnes, C.S.; Green, B.J. Comparative analysis of Sanger and Illumina Miseq sequencing for determining indoor fungal diversity. J. Allergy Clin. Immunol. 2017, 139, 86. [CrossRef]

66. Daniell, H.; Lin, C.-S.; Yu, M.; Chang, W.-J. Chloroplast genomes: Diversity, evolution, and applications in genetic engineering. Genome Biol. 2016, 17, 134. [CrossRef]

67. Krzewicka, B.; Smykla, J. The lichen genus Umbilicaria from the neighbourhood of Admiralty Bay (King George Island, maritime Antarctic), with a proposed new key to all Antarctic taxa. Polar Biol. 2004, 28, 15-25. [CrossRef] 
68. Krzewicka, B. Umbilicaria rhizinata comb. nov. (lichenized Ascomycota). Lichenologist 2010, 42, $491-493$. [CrossRef]

69. Beyer, L.; Bölter, M.; Seppelt, R.D. Nutrient and thermal regime, microbial biomass, and vegetation of Antarctic soils in the Windmill Islands region of East Antarctica (Wilkes Land). Arct. Antarct. Alp. Res. 2000, 32, 30-39. [CrossRef]

70. Krzewicka, B.; García, M.A.; Johansen, S.D.; Sancho, L.G.; Martín, M.P. Morphological and nuclear ribosomal DNA data support distinguishing two new species of Umbilicaria (Umbilicariaceae, Ascomycota) from Europe. Lichenologist 2009, 41, 631-648. [CrossRef]

71. Davydov, E.A.; Peršoh, D.; Rambold, G. Umbilicariaceae (lichenized Ascomycota)—Trait evolution and a new generic concept. Taxon 2017, 66, 1282-1303. [CrossRef]

72. Nayaka, S.; Upreti, D.K. Schirmacher Oasis, East Antarctica, a lichenologically interesting region. Curr. Sci. 2005, 89, 1069-1071.

73. Harańczyk, H.; Nowak, P.; Bacior, M.; Lisowska, M.; Marzec, M.; Florek, M.; Olech, M.A. Bound water freezing in Antarctic Umbilicaria aprina from Schirmacher Oasis. Antarct. Sci. 2012, 24, 342-352. [CrossRef]

74. Khot, P.D.; Ko, D.L.; Fredricks, D.N. Sequencing and analysis of fungal rRNA operons for development of broad-range fungal PCR assays. Appl. Environ. Microbiol. 2009, 75, 1559-1565. [CrossRef]

75. Darienko, T.; Gustavs, L.; Eggert, A.; Wolf, W.; Pröschold, T. Evaluating the species boundaries of green microalgae (Coccomyxa, Trebouxiophyceae, Chlorophyta) using integrative taxonomy and DNA barcoding with further implications for the species identification in environmental samples. PLoS ONE 2015, 10, e0127838. [CrossRef]

76. Darienko, T.; Gustavs, L.; Mudimu, O.; Menendez, C.R.; Schumann, R.; Karsten, U.; Friedl, T.; Pröschold, T. Chloroidium, acommon terrestrial coccoid green alga previously assigned to Chlorella (Trebouxiophyceae, Chlorophyta). Eur. J. Phycol. 2010, 4, 79-95. [CrossRef]

77. Turmel, M.; Otis, C.; Lemieux, C. Dynamic evolution of the chloroplast genome in the green algal casses Pedinophyceae and Trebouxiophyceae. Genome Biol. Evol. 2015, 7, 2062-2082. [CrossRef]

78. Turmel, M.; Otis, C.; Lemieux, C. The chloroplast genomes of the green algae Pedinomonas minor, Parachlorella kessleri, and Oocystis solitaria reveal a shared ancestry between the Pedinomonadales and Chlorellales. Mol. Biol. Evol. 2009, 26, 2317-2331. [CrossRef]

79. Guiry, M.D.; Guiry, G.M. AlgaeBase. World-Wide Electronic Publication, National University of Ireland, Galway. Available online: www.algaebase.org (accessed on 12 June 2019).

80. Thüs, H.; Muggia, L.; Pérez-Ortega, S.; Favero-Longo, S.E.; Joneson, S.; O’Brien, H.; Nelsen, M.P.; Duque-Thüs, R.; Grube, M.; Friedl, T.; et al. Revisiting photobiont diversity in the lichen family Verrucariaceae (Ascomycota). Eur. J. Phycol. 2011, 46, 399-415. [CrossRef]

81. Taton, A.; Grubisic, S.; Ertz, D.; Hodgson, D.A.; Piccardi, R.; Biondi, N.; Tredici, M.R.; Mainini, M.; Losi, D.; Marinelli, F.; et al. Polyphasic study of Antarctic cyanobacterial strains. J. Phycol. 2006, 42, 1257-1270. [CrossRef]

82. Hirano, M. Freshwater algae from Yukidori Zawa, near Syowa Station, Antarctica. Mem. Natl. Inst. Polar Res. Spec. Issue 1979, 11, 1-25.

83. Marshall, W.A.; Chalmers, M.O. Airborne dispersal of Antarctic terrestrial algae and cyanobacteria. Ecography 1997, 20, 585-594. [CrossRef]

84. Rikkinen, J. Molecular studies on cyanobacterial diversity in lichen symbioses. MycoKeys 2013, 6, 3-32. [CrossRef]

85. Casamatta, D.A.; Johansen, J.R.; Vis, M.L.; Broadwater, S.T. Molecular and morphological characterization of ten polar and near-polar strains within the Oscillatoriales (Cyanobacteria). J. Phycol. 2005, 41, 421-438. [CrossRef]

86. Davydov, D. Diversity of the Cyanoprokaryota in polar deserts of Rijpfjorden east coast, North-East Land (Nordaustlandet) Island, Spitsbergen. Algol. Stud. Arch. 2013, 142, 29-44. [CrossRef]

87. Zúñiga, C.; Leiva, D.; Carú, M.; Orlando, J. Substrates of Peltigera lichens as a potential source of cyanobionts. Microb. Ecol. 2017, 74, 561-569. [CrossRef]

88. Bates, S.T.; Nash, T.H., III; Garcia-Pichel, F. Patterns of diversity for fungal assemblages of biological soil crusts from the southwestern United States. Mycologia 2012, 104, 353-361. [CrossRef] 
89. Lamprinou, V.; Skaraki, K.; Kotoulas, G.; Economou-Amilli, A.; Pantazidou, A. Toxopsis calypsus gen. nov., sp. nov. (Cyanobacteria, Nostocales) from cave 'Francthi', Peloponnese, Greece: A morphological and molecular evaluation. Int. J. Syst. Evol. Microbiol. 2012, 62, 2870-2877. [CrossRef]

90. Tytgat, B.; Verleyen, E.; Sweetlove, M.; D’hondt, S.; Clercx, P.; Van Ranst, E.; Peeters, K.; Roberts, S.; Namsaraev, Z.; Wilmotte, A.; et al. Bacterial community composition in relation to bedrock type and macrobiota in soils from the Sør Rondane Mountains, East Antarctica. FEMS Microbiol. Ecol. 2016, 92, fiw126. [CrossRef]

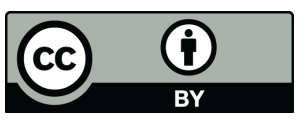

C 2019 by the authors. Licensee MDPI, Basel, Switzerland. This article is an open access article distributed under the terms and conditions of the Creative Commons Attribution (CC BY) license (http://creativecommons.org/licenses/by/4.0/). 